\title{
NORFACE
}

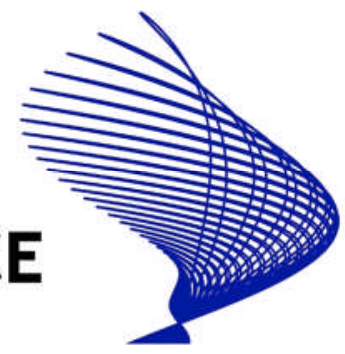

NORFACE MIGRATION Discussion Paper No. 2012-01

\section{Immigration: The European Experience}

Christian Dustmann and Tommaso Frattini 


\title{
"Immigration: The European Experience"*
}

\author{
Christian Dustmann, UCL and CReAM \\ Tommaso Frattini, University of Milan, LdA, CReAM and IZA
}

$\underline{\text { Revised version, November } 2012}$

\begin{abstract}
:
This paper starts with a brief historical overview of immigration in Europe. We then provide a comprehensive analysis of the skill structures of immigrants and their labor market integration in the different European countries, their position in the wage distribution, and the situation of their children, and illustrate the economic situation of immigrants and their children relative to natives. We show that immigrants - in particular those from non-EU countries - are severely disadvantaged in most countries, even if we compare them to natives with the same measurable skills. We conclude with a discussion of the role of regulations and institutions as one possible mechanism for these findings, and suggest directions for future research.
\end{abstract}

Keywords: Immigration, Europe, Integration, Institutions.

JEL Codes: J15, J61, J62

\footnotetext{
* Paper prepared for the volume "Immigration, Poverty, and Socioeconomic Inequality” published by the Russell Sage Foundation. We would like to thank David Card, Enrico Moretti and Steve Raphael for their constructive comments and suggestions on earlier versions of this paper. We also benefitted of the feedbacks from participants to the NPC Immigration, Poverty, and Socioeconomic Inequality Pre-Conference and Conference in Ann Arbor and Berkeley, respectively. We acknowledge support by the National Poverty Center at the University of Michigan, the Russell Sage Foundation and the Norface programme on migration.
} 


\section{Introduction}

For most European countries, large scale immigration is a more recent phenomenon than for countries like Australia, the US, or Canada. For instance, while Germany and Spain today have foreign born populations similar to the US in relative terms $(14.5 \%$ and $13 \%$ of their total populations, respectively), the share of foreign born on the overall population in West Germany before 1960 and in Spain before the early 1990s was below 1\%. In contrast, the foreign born population in the US was $12.5 \%$ in 2009 , but also $13.6 \%$ in 1900 . Immigration to Europe is also very heterogeneous: European countries have immigrant populations that differ in terms of ethnicity, origin, and educational attainment. For instance, while more than $70 \%$ of the foreign born population in Ireland comes from within the EU, this share is only $21 \%$ in the neighboring UK, where almost one third of the immigrant population comes from South Asia.

Why are immigrant populations so different across countries? And how are the different historical experiences of individual countries reflected in the current composition of immigrants and their labor market integration? We start our paper with a brief overview of the history of migration to European countries, where we highlight differences and similarities across countries. Based on the European Labor Force Survey we then analyze the composition of the stock and the flows of immigration to Europe and study the degree of labor market integration of immigrants in different countries. We show that immigrants in all countries are disadvantaged relative to natives in terms of their employment probabilities as well as their occupational distribution, and disproportionately represented in the bottom deciles of the national earnings distributions. The disadvantage is particularly pronounced for non-EU immigrants, who may face higher cultural and institutional barriers to access labor markets.

The children of immigrants, and particularly those of non-EU immigrants, represent in all countries a larger share of the overall children population than their parents' share is of the adult population. The economic disadvantage of immigrants is therefore a particular concern if it is 
transmitted to their children. We show that in all countries for which we have earnings information, the children of immigrants are disproportionately more likely to live in low income households than the children of natives.

We conclude our paper with a brief discussion of possible explanations as to why immigrants are disadvantaged throughout Europe, even if we compare them with native-born individuals with the same observable characteristics. We hypothesize that one reason may be barriers through institutions, and non-meritocratic access conditions to certain occupations and labor market segments, and we provide some descriptive evidence that is compatible with this hypothesis.

The rest of the paper is structured as follows: in section 2 we provide an overview of the history of migration in Europe, and discuss the role of undocumented immigration. Section 3 describes the European Labor Force Survey dataset. In section 4 we analyze the educational attainment and labor market outcomes of immigrants, while in section 5 we study immigrants' position in the national wage distribution. Section 6 investigates the relative situation of the children of immigrants and natives. We discuss our findings and conclude in section 7.

\section{Migration to Europe - A brief Historical Perspective}

We commence by briefly discussing immigration to European countries after WW2. The heterogeneity in migrations experienced across countries is enormous over this period. While some countries experienced large immigrations over the second half of the last century, others have been predominantly emigrations countries, and others again have changed from emigration countries to immigration countries. Countries differ also in the type, origin and composition of their immigrant populations. 


\section{Population Movements after World War II}

The peace treaties at the end of the second world war lay the foundation for the new geopolitical landscape of after-war Europe, and created large population movements within Europe and into Europe. Countries like Germany and Austria were substantially reduced in their national boundaries, and other countries incorporated new areas into their national geography. Further, the beginning of the cold war created a politically and economically divided Europe, with a new border separating Western Europe from Central and Eastern Europe, and creating separate political structures and economic systems. The after-war period also saw a continuation of the process of de-colonization, with withdrawal of the old Colonial powers from their former colonies. Strong economic growth in some European countries in the decades between the mid1950's and the mid-1970's led to large immigration movements from the periphery of Europe into its centre, and from countries to which links existed through colonial histories. In addition, the foundation of the European Economic Community in 1957 and its subsequent expansion, establishing an ever larger common market with free movement of people, goods and capital affected migration movements. And finally, the collapse of the Soviet empire led to conflicts and refugee movements as a consequence of a worldwide political and economic re-structuring, as well as previously suppressed intra-European movements.

\section{Immediate after-war period}

An immediate consequence of the re-partitions and political separations following WWII were large intra-European movements, due to displacement and forced resettlement. The country foremost affected by immigration during the period after 1945 was Germany. According to Salt and Clout (1976), by 1950 7.8m refugees had found a new home in West Germany, and 3.5m refugees in East Germany. Refugees were largely displaced ethnic German populations from 
new Eastern block countries like Poland, Czechoslovakia, Hungary and the USSR, or refugees who resettled for political reasons. These movements gradually ebbed away as Eastern European countries became increasingly insulated, symbolized by the building of the Berlin wall in 1961 .

Economic expansion and de-colonization

Starting in the early 1950s, European countries experienced a second large migration wave, quite different in nature from the first wave. This time the movement was one from Southern Europe, as well as non-European Mediterranean countries and former colonies, into Western and Northern Europe. Reasons for these movements were a combination of the tremendous economic expansion, due to reconstruction of the economies of Northern European countries, coupled with serious labor shortages, as well as de-colonization of former colonial powers. A most significant feature of these migrations was that they drew ethnically diverse populations into European countries which so far had been ethnically homogenous.

Many European colonial powers like the UK, France, Netherlands, Belgium, and Portugal lost their colonies in the decades after the Second World War. Important events were the independence from Great Britain of India and Pakistan in 1947 and of Ghana in 1957, Congo’s independence from Belgium in 1960, and Algeria's independence from France in 1962. Population movements from the former colonies to the mother countries were initially facilitated by former colonial powers granting rights to citizens of former colonies. De-colonization let Europeans who had settled in former colonies, sometimes for several generations, migrate back after colonial rule had ceased, but it also saw citizens of former colonies moving to Europe, sometimes for political, but more often for economic reasons. During this period, countries like the Netherlands received immigrants from Indonesia in the 1950s and from Surinam in early 1970s, the United Kingdom received immigrants from the Caribbean, Asia, and East Africa - 
with, for instance, 20.000 Ugandan Asians in 1972 alone migrating to the UK as a result of political persecution. After the Algerian war in 1962, France received one million Algerians of European origin (McDonald 1965), as well as many Northern African immigrants. It is these populations and their children that were at the root of recent social tensions, for instance in the Netherlands in 2004 and in France in 2005.

These large inflows were initially quite easily absorbed, due to the economic expansion of Western and Northern Europe, and the accompanying need of their industries for low skilled labor. In fact, immigrants were largely welcomed and immigrations were encouraged. While former colonial powers like France and the UK drew mainly on their former colonies to satisfy demands for unskilled labor, other countries, like Germany, Austria, or the Scandinavian countries, actively recruited workers predominantly from the Southern peripheries of Europe, the Mediterranean countries, as well as from Turkey. Recruitment of a migrant unskilled workforce was usually regulated by bilateral agreements. An important feature of these migration movements was that they were considered as temporary, and migrants were expected to return to their home countries after the economic boom had ebbed. In the absence of any contractual or legal arrangements as to their temporary status, however, a large fraction of immigrants settled permanently. By 1973, the total foreign population in Germany alone had grown to $3.9 \mathrm{~m}$, or $9.8 \%$ of the population.

This second large immigration wave came to a halt with the first oil crises in 1973, leading to an economic downturn and a sharp increase in unemployment in most Western and Northern European countries. Nevertheless, immigration did not cease after 1973. Many immigrants settled more permanently and were joined by their families. As a consequence, migration into Northern Europe between 1973 and 1985 was predominantly characterized by family reunification. 
The period between 1950 and 1973 saw opposite movements in Southern European countries. Southern Europe during the 1950's and 1960's was economically a mirror image of Northern Europe, with sluggish economic development and high unemployment. The booming North was a magnet for people, and Southern Europe was characterized over this period by out-migration, and to some extent return migration.

Eastern and Central European countries during this period were hidden behind the iron curtain. Although they did not participate in the large economic boom experienced by many Northern European countries, there was substantial difference in economic growth and prosperity, which, in a similar way, led to migration movements mainly for economic reasons.

\section{Fall of the Berlin Wall}

A next big population movement was initiated in the late 1980's by a liberalization of Soviet policy and accelerated by the fall of the Berlin wall in 1989. In an initial phase, liberalization led to large East-West migrations, predominantly of people whose movements were suppressed during the Soviet era. Most significant was the movement of Ethnic Germans from Eastern Europe and the former Soviet Union to Germany. In 1990 alone over 397,000 Ethnic Germans came to Germany from Eastern Europe and the former Soviet Union. During the 1990s the inflow of Ethnic Germans from former Soviet Union remained high, with over 700,000 entering Germany between 1996 and 2001 (Glitz 2012).

The collapse of Soviet rule in the early 1990s led to a wave of civil conflict and separations, with large displacements of civil populations. The Balkan wars led to large asylum and refugee migrations. This time however migrations were not only targeting Northern Europe, but also Southern European countries, which had, partly as a result of their incorporation into the European Union, experienced rapid economic development and convergence to Northern 
Europe during the 1980’s. Immigration was not only limited to former Western European countries, however. The fall of the iron curtain and the transition of former Soviet Bloc countries to free market economies led to differential economic developments in these countries, triggering migration flows from the poorer countries to the richer countries. During the Balkan wars, those countries who either had already large populations from ex-Yugoslavia, like Germany or Austria, and countries who were immediate neighbors, like Greece, experienced large in-migrations. This wave of immigration ebbed down towards the end of the 1990's, when the conflicts ended.

\section{EU Eastern enlargement and beyond}

The next wave of movements in Europe was mainly internal, and triggered by the expansion of the European Union towards the former Easter European countries. European legislation foresees that citizens of countries that join the European Union can freely move across those countries. However, pre-existing member states may impose, during a 7-year transition period, limitations to the employment of citizens of new-member countries (see Dustmann, et al. 2003 for details). After EU accession of 8 Central and Eastern European countries on May $1^{\text {st }}, 2004$ the UK, Sweden and Ireland allowed citizens of the new accession countries to work in their labor markets immediately, which lead to sizeable movements from particularly Poland (the largest of the new accession countries) into these countries. It is estimated that between 2004 and 2008, Poland experienced the net outflow of over 300,000 citizens, or about $1 \%$ of the total population (see Dustmann, Frattini, Rosso 2012). Also, enlargement led to movements into other European countries like Italy and Spain. Although new EU citizens were allowed to freely travel to these countries, taking up an employee job was illegal, and led many new accession citizens to engage in illegal work relationships. Further, continuing conflicts around the world, and improved travel and information technologies dramatically increased the pressure on 
Europe's Southern borders, with countries like Italy and Greece receiving large inflows of asylum and illegal immigrants, many arriving by boat on largely uncontrollable sea borders.

Table 1 illustrates the magnitude and the composition ${ }^{1}$ of immigrant populations in different European countries as of 2007-2009, and contrasts them to the US.

[Table 1 here]

In many of the countries in the Table, the stock of immigrants in total population is above $10 \%$. Southern European countries and the Nordic countries tend to be those with the lowest immigrant populations, with the exception of Sweden (15\%) and Spain (13\%). Overall, more than $11 \%$ of the population in European countries is foreign-born. This is only one percentage point lower than the US. However, the composition of the immigrant population differs widely between Europe and the US. While in the US over 50\% of the foreign born population comes from Latin America, this share is only 12\% in Europe. Similarly, one in four immigrants in the US comes from South and East Asia, compared to only 11\% in Europe. Within Europe, there is substantial heterogeneity across countries. The colonial heritage and cultural ties are evident in the composition of the immigrant population in Spain, with $47 \%$ of the foreign born residents coming from Latin America; France, with $40 \%$ of immigrants coming from North Africa; Portugal, with 45\% of immigrants from Africa and 21\% from Latin America; and for the UK, with 29\% of immigrants coming from Asia.

The data in Table 1 are likely to be an underestimate of the total stock of immigrants residing in European countries, as they do not include undocumented immigrants. Quantifying the size of undocumented migration in Europe is difficult as EU member states do not apply comparable internal apprehension practices, and comparison of country-specific migration-control data is therefore not viable. Estimates of the undocumented populations will therefore have to rely on

\footnotetext{
1 EU15 countries: Austria, Belgium, Denmark, Finland, France, Germany, Greece, Ireland, Italy, Luxembourg, Netherlands, Portugal, Spain, Sweden and United Kingdom; New Member States 12 (NMS12): Bulgaria, the Czech Republic, Estonia, Cyprus, Latvia, Lithuania, Hungary, Malta; Poland, Romania, Slovenia, Slovakia.
} 
country-by-country estimates, which are likely to differ in their methodology, timeliness, and reliability. According to the recent estimates of Kovacheva and Vogel (2009), which are based on collection and harmonization of estimates from several national sources, the number of immigrants illegally residing in the EU 15 countries ranged in 2008 between 1.8 and 3.3 million, or between $0.46 \%$ and $0.83 \%$ of the total population. According to these estimates, between $7 \%$ - 12\% of the total EU 15 immigrant population would be undocumented. In contrast, Hoefer et al. (2010) estimate that 10.8 million unauthorized immigrants, or about $28 \%$ of the total immigrant population, were living in the US as of January 2009. Based on these estimates, undocumented immigrants are a much larger share of the population in the US than in Europe. However, the estimates of undocumented immigrants vary largely across EU countries. Table 2 is adapted from Vogel and Kovacheva (2009), and reports country-by country estimates of the magnitude of the unauthorized immigrant population in EU 15 countries in 2008, while the last row reports for comparison estimates for the US, based on Hoefer et al. (2010).

[Table 2 here]

The figures should be interpreted with caution, given the likely poor quality of estimates for the illegal population of immigrants in the European countries. The estimates suggest that undocumented immigration is close to zero in the Scandinavian countries (except for Finland, where legal immigrants represent less than $3 \%$ of the total population, see Table 1 ). On the other hand, the undocumented population is estimated to be much larger in Southern European countries (except for Spain) and in countries like the Netherlands, and the UK The upper bound estimates for Portugal and the UK point at one in four immigrants being undocumented. Note also that the size of the undocumented population in countries like Italy and Spain fluctuates considerably over time, due to repeated amnesties (see Fasani 2010). 


\section{Data}

The study of European immigration is not straightforward, due to the scarcity of European-wide datasets. Furthermore, a problem for multi-national comparisons is the definition of “immigrants”. In Anglo-Saxon countries “immigrants” are people who were born outside their country of residence. In countries with citizenship based on blood ancestry, however, a translation of "immigrants" can include people who were born in the country but are not citizens (e.g., children of Turkish nationals born in Germany). Likewise, people who were born abroad but of the right ancestry may not be classified as "immigrants", as is the case for ethnic Germans born in Eastern Europe who moved to Germany after 1990. In this paper, we rely on information on country of birth to define immigrants. However, when we distinguish by areas of origin (including EU or non-EU) we have to base the classification on nationality for Germany, while we can still use country of birth for other countries.

Our analysis is based on the European Labor Force Survey (EULFS). The EULFS is conducted in the 27 Member States of the European Union and two countries of the European Free Trade Association (EFTA). It is a large quarterly household sample survey of people aged 15 and over as well as of persons outside the labor force. The National Statistical Institutes of each member country are responsible for selecting the sample, preparing the questionnaires, conducting the direct interviews among households, and forwarding the results to Eurostat in accordance with the common coding scheme. The data collection started in 1983, though not all countries are included in all years. In spring 2002, the LFS sample size across the EU was about 1.5 million individuals. The EULFS collects information on respondents' personal circumstances (including nationality, country of birth, and years of residence in the host country if applicable), their household structure and their labor market status during a reference period of one to four weeks immediately prior to the interview. However, the EULFS does not have information on respondents' ethnicity. Also, information on household structure is not currently available for 
Denmark, Finland, Norway and Sweden. Since 2009, and for that year only, the EULFS provides, for some countries, information on individuals' position in the national distribution of take home wages. This information is available for Belgium, Germany, Finland, France and Italy only ${ }^{2}$.

We focus our analysis on 15 Western European countries: 14 were members of the European Union in 1995, and Norway. To have a large enough sample size, we pool together years 20072009. The main reason for not considering the new East European accession countries is that their experience as immigrant-receiving countries is very recent, and they have small immigrant populations.

\section{Education and Labor market outcomes}

In this section we investigate the labor market performance of immigrants in Europe. We first analyze immigrants' educational achievements, relative to natives, in the different countries we consider. The analysis relies on the variable "highest qualification achieved", which is coded in each country according to the ISCED (International Standard Classification of Educations) ${ }^{3}$.

\section{Educational Attainment}

Table 3 reports in the left columns the share of natives and immigrants with lower-secondary education (ISCED levels 0-2), while the right columns report the share of natives and immigrants with tertiary (ISCED levels 5 and 6) education, for each country.

\footnotetext{
${ }^{2}$ The current (2010) EULFS release contains the income decile variable for Greece, Portugal and the UK as well, but in these countries there are relevant coding errors, so we exclude them from our analysis.

${ }^{3}$ This classification may be problematic for two reasons. A first general problem is that ISCED may not reflect adequately the educational system of all countries, and can therefore lead to difficulties in cross-country comparisons. A second problem, specific to immigration, relates to the fact that foreign qualifications have to be first "translated" into a country-specific qualification, and then each country’s qualification is recoded according to ISCED.
} 
[Table 3 here]

The numbers show that on average immigrants in Europe are slightly less educated than natives: the share of individuals with tertiary (lower secondary) education is $24 \%$ (38\%) among immigrants and 26\% (32\%) among natives. Further, there is a positive correlation between natives’ and immigrants' qualifications: the correlation coefficient between the share of tertiary (lower secondary) educated immigrants and natives is 0.7 (0.6), and strongly statistically significant. These numbers conceal the substantial differences that exist across countries of origin, even within destination country. The last column of Table 3 reports the (unweighted) standard deviations of the share of lower secondary educated immigrant from different origin groups within each country. It shows that there is considerable heterogeneity in the educational attainment of different immigrant groups within the same destination country (see Dustmann and Glitz 2011 for more details).

We investigate differences in educational attainments across countries of origin in Table 4, where we pool all European countries of destination.

[Table 4 here]

The figures in the table show that North American and Oceanian immigrants are better educated than natives: almost 50\% of individuals from these groups have a tertiary education, while only $14 \%$ have less than secondary education. On the contrary, non-EU European and North African immigrants appear to have lower levels of education than natives, with about $50 \%$ of immigrant from these areas having at most a lower secondary education. EU15 immigrants have instead a similar educational distribution to non-immigrants, though more polarized with a higher share of both lower secondary and tertiary educated persons. Even more dramatic is the polarization of African and Asian immigrants, who display a higher tertiary education rates than European natives, but a substantially larger share of low-educated individuals. 


\section{Employment}

Figure 1 reports differences in employment probabilities between immigrants and natives across the different countries we consider.

[Figure 1 here]

The darker bars report the unconditional immigrant-native difference in employment probabilities (net of year and seasonality effects) ${ }^{4}$. These figures show that in most countries immigrants experience a substantial labor market disadvantage. In Spain and Ireland employment rates of natives and immigrants are not significantly different, while in Greece, Italy and Portugal (all three immigration countries only since the late 1990’s), immigrants have higher probability of employment than natives.

To what extent are these differences due to a different composition of the immigrant and native workforce in terms of age, education (see Table 3), and gender mix? The lighter bars of figure 1 display differences in probability of employment after conditioning on these variables, as well as on the region of residence within a country (see footnote 4 for details). The figure shows clearly that if immigrants and natives lived in the same areas, and were identical in their demographic characteristics, immigrants would still be worse off in most countries. Moreover, conditioning on observable characteristics turns the immigrant-native employment differential negative also in Ireland, Italy and Portugal, and eliminates the positive difference in Greece. Thus, comparing immigrants to natives with the same observable characteristics, and who live in the same geographical areas, shows that immigrants have lower employment probabilities than natives in all countries, except for Greece, where differences disappear.

\footnotetext{
${ }^{4}$ Here and below, "unconditional" differences in employment probabilities between immigrants and natives are obtained as coefficients on a foreign-born dummy in a regression of a dummy for employment on the foreign-born dummy and year-quarter interaction dummies. "Conditional" differences are obtained from the same regression augmented with a gender dummy, regional dummies, dummies for five-year age brackets, and dummies for lowersecondary, secondary, and tertiary education. We run separate regressions by country, and compute heteroscedasticityrobust standard errors.
} 
We have shown above that the composition of the immigrant population varies across European countries, and that different origin groups differ, for instance, in their human capital. How do immigrants from different origin regions compare to natives within each of the countries we consider? In Table 5 we report employment probability differentials where we distinguish between EU and non-EU immigrants, with natives of each country as the reference group.

\section{[Table 5 here]}

Columns 1 and 2 show that in all countries (with the exception of Greece, Spain and Italy) EU immigrants perform better than non-EU immigrants: the difference in EU immigrants' employment rate relative to natives is at least half that of non-EU immigrants. In columns 3-4 and 5-6 we gradually make immigrants "more similar" to natives. Columns 3 and 4 report the difference in employment probability of EU and non-EU immigrants relative to natives, after controlling for gender composition and regional distribution. The results are only marginally different from those in Columns (1) and (2). In columns 5 and 6, we control additionally for differences in age and education between the two populations. This eliminates any difference in the employment probability of natives and EU immigrants in Finland, France, Greece, and Norway, while EU immigrants have a higher probability of employment than natives in the UK. In the other countries, the employment gap ranges between 7.9 percentage points in Sweden and 2.7 in Italy, in favor of natives. Non-EU immigrants are significantly more disadvantaged in all countries. Even if they had the same characteristics as natives, they would still have an employment probability that is 20 percentage points lower than natives in Belgium, 16 percentage points in Germany, 16 percentage points in the Netherlands and 17 percentage points in Sweden. 


\section{Occupational Distribution}

We now consider as a different dimension of immigrants' labor market integration their occupational distributions, and how these differ between immigrants and natives.

Table 6 reports the Duncan dissimilarity index for the distribution of EU (odd columns) and non-EU (even columns) immigrants and natives across occupations (at 1-digit ISCO level), corrected to account for sampling error ${ }^{5}$. The index can be interpreted as the percentage of immigrants that would be required to change occupation for immigrants and natives to have the same occupational distribution. Therefore, the higher the index, the more dissimilar is the occupational distribution of immigrants and natives.

[Table 6 here]

The first column of Table 6 reports the overall index for EU immigrants, while column 2 reports the overall index for non-EU immigrants, both relative to natives. The entries show that in most countries EU immigrants are more similar to natives in their occupational distribution than nonEU immigrants. The exceptions are the two countries with a colonial past, France and the UK, where non-EU immigrants have an occupational distribution that is closer to natives'. This may be related to the long experience of extra-European migration to these two countries from their former colonies. As we show below, the occupational distribution of immigrants and natives becomes more similar with time spent in the host country.

In general, Nordic and central European countries tend to have a more equal occupational distribution of immigrants and natives, relative to Southern European countries. For instance, in Finland just above $1 \%$ of $\mathrm{EU}$ (13\% of non-EU) immigrants would have to change jobs to equalize the occupational distribution of immigrants and natives. In the Netherlands, this share is about 5\% (15\%), while in Italy $27.5 \%$ (36\%) and in Greece 32\% (50\%).

\footnotetext{
${ }^{5}$ See Hellerstein et al. (2007) and Carrington and Troske (1997) for a similar approach to a different index.
} 
One reason for the differences in the occupational distribution of immigrants and natives might simply be the diversity in the composition of the two populations, e.g. due to different education structures. To address this, we divide the population in three education groups based on the ISCED (International Standard Classification of Education) classification, and compute the Duncan dissimilarity index within each group . We report the results in columns 3 to 8 . The index tends to be lower for low education groups, and to increase with the level of education, especially for non-EU immigrants, although there are several exceptions. Columns 9 and 10 report an average of the values of the Duncan index in each education group, weighted by the share of each group in the total population. This gives a measure of occupational dissimilarity conditional on the educational composition of immigrants and natives in each country. The values of columns 9 and 10 are, especially for non-EU immigrants, smaller than those of columns 1 and 2, but the pattern is very similar. This indicates therefore that differences in the educational composition are not the main reason for the differences occupational distribution of immigrants and natives.

How do immigrants assimilate in the host country labor market? Do they become more "similar" to natives in terms of their occupational distribution as their stay in the country increases? Figure 2 suggests that this is indeed the case.

[Figure 2 here]

In the figure we plot the value of the Duncan index versus years of residence in the host country for the five largest EU destination countries: Germany, France, Spain, Italy and UK. The top graph reports the index for EU immigrants, while the bottom graph displays the index for nonEU immigrants.

In all countries and for both EU and non-EU immigrants, the dissimilarity index decreases with years since migration: the longer the time spent in the host country, the more similar the 
occupational distribution of immigrants and natives becomes. An interesting feature of the figure is that, especially for non-EU immigrants, the relative ranking of countries remains quite stable over time. Italy is consistently the country with the largest dissimilarity between the occupational distribution of immigrants and natives (except for EU immigrants who have been in the country for more than ten years). Conversely, the UK is, especially for non-EU immigrants, the country with the highest occupational similarity (although $20 \%$ of non-EU immigrants who reside in the UK for no more than two years would have to change jobs for their occupational distribution to equalize that of natives). The changes of the index over time could also be due to changes in cohort composition, as well as selective out-migration. Changes in cohort composition may be particularly relevant in countries like Spain and Italy where immigration is a recent phenomenon, and immigrants who were in the country for more than ten years in 2007-2009 may differ substantially from later cohorts.

The analysis of the index of dissimilarity has shown that immigrants and natives are employed in different occupations, but it does not allow establishing whether immigrants are employed in "better" or "worse” occupations than natives.

We now measure the occupational status with the Socio-Economic Index of Occupational Status (ISEI). The ISEI is an index of occupational prestige which captures the attributes of occupations that convert education into income ${ }^{6}$. Higher values of the index correspond to occupations which reward education more, while lower values of the index denote occupations that have lower returns to education.

Figure 3 shows the differences in the distribution of EU (dashed line) and non-EU (dotted line) immigrants relative to natives across the ISEI scale. If immigrants and natives had the same occupational distribution, then both lines would be horizontal at 0 . The figure shows clearly that natives are more concentrated than immigrants in the more skilled (higher indexed) occupations.

\footnotetext{
${ }^{6}$ See Ganzeboom, De Graaf and Treiman (1992) for a description of the index and its construction.
} 
Within immigrants, non-EU immigrants are more concentrated than EU nationals in less skilled occupations.

[Figure 3 here]

Is this pattern common to all countries? We investigate the cross-country heterogeneity in occupational distributions in Table 7 , where we report the average standard deviation differences in the ISEI index between immigrants and natives in each country.

[Table 7 here]

Columns 1 and 2 report unconditional differences, controlling for year and seasonality only. Non-EU immigrants (column 2) are employed in lower skilled occupation than natives in all countries, except for Ireland and Portugal, where the average value of the index is the same for both extra-EU immigrants and natives. In the UK, non-EU immigrants are on average employed in slightly more skilled occupations than natives (7\% of a standard deviation). Southern European countries (except for Portugal) are those where the gap between immigrants and natives is highest, between $2 / 3$ and $4 / 5$ of a standard deviation, while in Nordic countries the gap is about $1 / 3$ of a standard deviation, and a bit lower in Finland. EU immigrants, conversely, have markedly different performances in different European countries. In Austria, Belgium, Denmark, Finland, Norway and Portugal they are employed in more skilled occupations than natives, with an advantage as high as $1 / 3$ of a standard deviation in Portugal. Conversely, in Germany, Spain, France, Greece, Ireland, Italy and the UK EU immigrants are employed in less skilled occupations than natives. Interestingly, in France and in the UK the gap with natives in occupational prestige is higher for EU than for non-EU immigrants.

In columns 3 and 4 we control for differences in gender composition, regional distribution, age structure, and education of immigrants natives. This has important effects for both EU and nonEU immigrants. Once individual characteristics are controlled for, EU immigrants turn out to be 
employed in less skilled occupations than natives in all countries, except for Belgium where there is no significant difference, and for Finland, where the occupational advantage of EU immigrants is even magnified. Among non-EU immigrants, the difference turns negative also in Portugal and Ireland, where there was no unconditional difference with natives, and in the UK. Non-EU immigrants in the UK now display an occupational gap of over $10 \%$ of a standard deviation relative to British natives.

The previous figures show the distribution of immigrants relative to natives across occupational categories. But how are immigrants allocated to occupational categories within larger occupational groups? This is shown in columns 5 and 6 , where we condition on dummy variables for one-digit ISCO occupations. Thus, the entries in these columns measure the difference in occupational prestige between immigrants and natives within one digit occupations. Although the gap reduces dramatically in all countries, it is still negative for most countries for EU immigrants, and negative and significant everywhere for non-EU immigrants. Thus, even within broad occupational classes, non-EU immigrants are employed in more unskilled occupations than natives. EU immigrants are more similar to natives: : in countries like Ireland and the Netherlands, there are no differences in occupational prestige between natives and EU immigrant within the same occupation group, while in Sweden EU immigrants are employed in slightly more skilled jobs, within the same occupation group.

\section{Immigrant's position in the earnings distribution}

As discussed above, there are no good Europe-wide dataset with reliable wage measures, and sufficient numbers of observations to investigate immigrant populations. For this section we therefore use information on individuals' position in the national distribution of monthly take home pay from main job from the 2009 EULFS. We focus here on Belgium, Germany, Finland, 
France and Italy, the only countries where the information is available, and consider all employed individuals with information on position in the distribution of earnings.

Figure 4 displays the share of natives, EU, and non-EU immigrants in each decile of the national earnings distribution. If immigrants and natives were equally distributed, the three lines would be flat, and overlap.

[Figure 4 here]

The Figure shows clearly that this is not the case. Non-EU immigrants have on average lower earnings than EU immigrants and natives. About 15\% of non-EU immigrants are in the bottom decile of the earning distribution, while another $15 \%$ are in the second decile. Among EU immigrants, $14 \%$ are in the first decile, and about $13 \%$ in the second, while slightly less than $10 \%$ of natives are in each of these two lowest deciles. The distribution of immigrants across deciles is decreasing, with an increasingly lower share of immigrants in higher deciles. However, the decrease is much faster among non-EU immigrants, while the distribution of EU immigrants is relatively flat at around $9 \%$ above the median.

Immigrants, and especially non-EU immigrants, are therefore clearly disadvantaged in terms of income relative to natives, and are over-represented in the bottom part of the income distribution.

We explore more in detail differences across areas of origin in Table 8, where we report the share of natives and immigrants in each decile of the national earnings distribution, and we distinguish between immigrant groups.

[Table 8 here]

Immigrants from all areas are more likely than natives to be in the bottom deciles of the earnings distribution, except for those from North America and Oceania. Latin American immigrants are most disadvantaged: $21 \%$ are in the first decile, and a further $20 \%$ is in the second decile. 
Citizens of the new EU member states are also among the most disadvantaged groups, with 19\% of them in the bottom decile, and $17 \%$ in the second decile.

For most origin groups, the distribution over earnings deciles is roughly decreasing. The exceptions are North Americans and Oceanians, for which the distribution is increasing (though not monotonically), and EU15 immigrants. The latter group has a clearly U-shaped distribution, with higher density at the two tails, and a lower concentration in the central deciles.

In Table 9 we study the probability of being in the lowest earnings decile, and analyze differences across destination countries, and we distinguish between EU and non-EU immigrants.

[Table 9 here]

Columns 1 and 2 report differences between EU (column1) and non-EU (column 2) immigrants in the unconditional probability of being in the bottom decile of the earnings distribution (net of seasonality effects) ${ }^{7}$. In all countries both EU and non-EU immigrants are more likely than natives to be in the bottom decile, except for Finland where there are no differences between natives and EU immigrants. Italy is the country where EU immigrants experience the highest disadvantage relative to natives: their probability of being in the bottom decile is 9 percentage points higher than natives, while it is just above 3 percentage points for EU immigrants in Belgium and Germany. Italy is also the only country where EU immigrants are worse off than non-EU immigrants, relative to natives. Conversely, in Finland extra-EU immigrants are more than 11 percentage points more likely than natives and EU immigrants to be at the bottom of the earnings distribution.

\footnotetext{
${ }^{7}$ The unconditional differences in the probability of being in the bottom decile of the distribution of earnings between immigrants and natives are obtained as coefficients on EU and non-EU immigrant dummies in a regression of a dummy for being in the bottom decile of the national earnings distribution on the foreign-born dummies and quarter dummies. "Conditional" differences are obtained from the same regression augmented with a gender dummy, regional dummies, dummies for five-year age brackets, dummies for lower-secondary, secondary, and tertiary education, and dummies for 1-digit ISCO codes. We run separate regressions by country, and compute heteroscedasticity-robust standard errors.
} 
In columns 3 and 4 we investigate to what extent the differences in the probability of being at the bottom of the distribution of earnings are due to differences in immigrants' and natives' characteristics. We report probability differentials after accounting for differences in gender, age, and education, and for the regional distribution of immigrants and natives, which accounts for the fact that immigrants are likely to settle in the areas with higher wage levels. Conditioning on these characteristics reduces slightly the difference between natives and EU immigrants in Germany and Italy, while it has no effect in other countries. As regards non-EU immigrants, after controlling for all observable characteristics, the probability of being at the bottom of the earnings distribution increases in Finland and France, while it decreases in Belgium and Germany and is unaffected in Italy. Finally, in columns 5 and 6 we compare immigrants and natives within the same broad occupation group (1-digit ISCO code). As expected, in most countries controlling for 1 digit occupation makes the probability of being in the bottom decile more similar between immigrants and natives. However, except for Germany, even within the same broad occupation group immigrants are more likely than natives to be at the bottom of the distribution of earnings.

\section{Children of Immigrants}

The economic and social integration of the descendants of immigrants is likely to be one of the key challenges for many European countries over the next decades. As we show in section 2, many European countries have only a short history of immigration, but the children of immigrants are a sizable and increasing fraction of their populations.

Table 10 reports the share of children with immigrant parents over all children under the age of 15, for all the countries for which we have information on household composition. We distinguish between children of EU and non-EU immigrants, and of mixed couples, where we 
differentiate between different parental mixes. We also report, for comparison, the share of EU and non-EU immigrants among the adult population (15 and over).

[Table 10 here]

In all countries the descendants of non-EU immigrants account for a larger share of the children population than their parents' share of the adult population, while the fraction of children of EU immigrants in the children population is slightly smaller than the share of their parents' in the adult population. Across all countries, EU immigrants account for $2.6 \%$ of the adult population, while their children make up $1.9 \%$ of the population below the age of 15 . Non-EU immigrants instead represent $6 \%$ of the adult population, but their children account for $9.4 \%$ of all children. This is interesting, and may suggest a higher fertility of non-EU immigrants, which will importantly shape the ethnic mix in the future. Moreover, almost $8.5 \%$ of children are from mixed couples, with 3\% having a native and an EU immigrant parent and over 5\% having a native and a non-EU parent. Children of mixed EU/non-EU couples make up only $0.3 \%$ of all children.

For the countries where we have both information on individuals' position in the national distribution of earnings and information on household structure (Belgium, Germany, France, and Italy) we can study the extent to which children of immigrants are concentrated in poorest households. The EULFS does not provide information on household income. We therefore define as "low income" households those households where both the reference person and their spouse (if there is a spouse) are in the bottom decile of the earnings distribution. The first column of Table 11 shows that the share of households that satisfy this criterion is about $5 \%$ in Belgium, 4\% in Italy and France, and just over 1\% in Germany, while column 2 shows that the share of children living in "low-income" households is slightly lower than the share of households in that category. The remaining columns of Table 11 report the proportion of 
children of immigrants or of mixed couples out of all children that live in a low-income household, defined in this way.

\section{[Table 11 here]}

In all countries, the children of non-EU immigrants are much more likely than the children of natives to belong to a low-income household. For instance, in Italy the children of non-EU immigrants represent less than $8 \%$ of all children, but $20 \%$ of all children from low-income households. In Belgium, less than $11 \%$ of all children are the descendants of non-EU immigrants, but they account for $23 \%$ of children in "low income" households. Similarly, the children of EU immigrants are over-represented among low- income households in all countries except for Germany ${ }^{8}$. Italy is the country where the children of EU immigrants are relatively more likely to be from "low income” households: they account for less than $2 \%$ of all children, but 5.5\% of children from low income households. On the other hand, the percentage of children of mixed couples in low income households is lower than the percentage of all children in these households. If belonging to a poor household restricts future opportunities (see e.g. Blanden et al. (2007), Corak (2006), Jäntti et al. (2006), Solon (2002)), then these numbers suggest that the disadvantage of immigrants, particularly from non-EU countries, which we illustrate in the previous sections, may carry over to their children. Research by Dustmann, Frattini and Lanzara (2012) on the educational attainments of the children of immigrants is partly in line with this: They find that gaps in test scores between children of immigrants and children of natives in different countries are strongly related to their parents’ achievement. However, their results also show that differences in parental background alone do not account everywhere for the entire immigrant-native achievement gap. In traditional immigration countries, like the Anglo-Saxon countries, differences in test score gaps between children of immigrants and children of natives disappear after conditioning on family characteristics. In many European countries, instead,

\footnotetext{
${ }^{8}$ Note however that the sample of children from "low income” households in Germany is very small.
} 
significant differences in test scores between natives and immigrants remain, even after controlling for family characteristics. This suggests that there may be considerable diversity in educational institutions between countries, possibly related to their experience with larger scale immigration.

\section{Discussion and Conclusion}

This paper provides an overview of immigration to Europe, and of the experience of immigrants in the European labor markets. Our brief historical review shows that the different historical circumstances of European countries (like their colonial past) as well as their economic developments, and the demand for labor of their industries in the period after the Second World War, led to different immigration intensities from different origin countries. As a result, different countries in Europe today are home to very dissimilar immigrant populations, in terms of origin, ethnicity, and education. Further, while some countries were home to large immigrant populations already in the 1960's, others experienced large immigration only over the last two decades. Overall, however, large-scale immigration, and in particular immigration from remote parts of the world, is a far more recent phenomenon for any European country, in comparison to the US.

Across all countries in Europe, immigrants tend to have lower levels of education than natives, with the exception of the UK. There is a large variation in educational attainments of immigrants according to their origin countries. Further, immigrants tend to have lower employment probabilities. Similarly, we find that in most countries immigrants hold jobs that are lower ranked in terms of their income potential, even conditional on education. This is particularly the case for non-EU immigrants, who are employed in lower ranked occupations than natives in all countries. 
Investigation of the position of immigrants in the overall wage distribution of the receiving countries is - due to data availability - restricted to a subset of countries: Belgium, Germany, Finland, France and Italy. The picture that emerges is in line with our previous findings: Immigrants are predominantly positioned at the lower parts of the overall wage distributions. Again, we establish large differences according to origin country: While immigrants from the EU15 countries are fairly similarly distributed across wage distribution deciles to natives, immigrants from non-OECD countries are more likely than natives to be at the bottom of the wage distribution. Consistent with our results on employment probabilities and occupational distribution, differences in education and demographic characteristics between immigrants and natives do not explain these wage differences.

Disadvantage seems to be transferred to the next generation: We show that an overproportionally large fraction of the children of immigrants, in particular those from non-EU countries, grow up in households that are at the very bottom of the income distribution. About $3 \%$ of all households consist of parents who are both in the lowest decile of the earnings distribution (or a single parent who is). These households have about $2.5 \%$ of all children below the age of 15 . However, $3.6 \%$ of all children with EU-immigrant background live in such households, and nearly $20 \%$ of all children with a non-EU immigrant background. These numbers are quite dramatic, and suggest that disadvantage and poverty affects a substantial fraction of immigrant children.

What are the conclusions we can draw from this? The picture which emerges for Europe's immigration experience is one of considerable heterogeneity of immigrant populations across the different recipient countries, in terms of ethnicity and country of origin, as well as in terms of education. Across all countries, it seems that immigrants are economically disadvantaged, even if we compare them to natives with the same characteristics. This disadvantage is more pronounced for immigrants from non-EU countries. As we also point out, in comparison with 
the US, immigration to Europe is a relatively recent phenomenon. Thus, one reason for the disadvantaged situation of immigrants may be that institutions in European countries have not yet been sufficiently adapted to accommodate foreign born individuals. The large inflows of immigrants into most European countries over the last decades were seldom accompanied by a clear immigration policy or strategies about the long-term integration into economic and social structures. For instance, access to many jobs may require types of "social capital” immigrants usually do not have, or access may not be based on meritocratic considerations only. Also, recognition of education and experience acquired in the home countries may be difficult, due to rigid regulations. This might be more of a problem for non-EU immigrants, as EU laws facilitate access of EU immigrants to labor markets of EU member states. On the other hand, in countries like the US, with a long history of large-scale immigration, institutions may have adjusted over the decades and centuries.

To investigate this further is in our view an interesting and exciting research agenda, with important implications for policy. Although this is beyond the scope of this paper, we would like to conclude with some evidence which is in line with this hypothesis. As we explain above, there is some considerable variation across European countries in their exposure to immigration over the period since 1950. This allows us to address the question whether the employment gap between immigrants and natives, or the occupational segregation, is larger in countries with a more recent immigration experience. In Figures 5 and 6 we plot the index of occupational dissimilarity between recent immigrants (who have been in the country for at most two years) and natives, and the gap in employment probability gap against the share of foreign born in 2010 over the share of foreign born in $1960^{9}$, for the European countries in our data set. The latter is an indicator for the length of "exposure” that countries have to foreign born individuals.

\footnotetext{
${ }^{9}$ Data are from the World Bank World Development Indicators. Historical immigration figures are not available for Germany.
} 
[Figure 5 and Figure 6 here]

The figures clearly illustrate that both occupational dissimilarity and employment gaps are larger for countries where the ratio of the foreign born share in 2010 to 1960 is larger. In particular, a longer exposure to immigration has a greater effect on the labor market assimilation of non-EU immigrants, while it does not impact on employment probability differential for EU immigrants.

Although these figures are merely suggestive and have to be evaluated with care, they are compatible with the hypothesis that the disadvantage of immigrant populations and their children is partly related to institutions and perhaps the accessibility of labor markets on meritocratic grounds. To explore this further, we plot in figures 7 and 8 the index of occupational dissimilarity and the employment probability gap for recent immigrants relative to natives against the 2008 OECD index of strictness of employment protection legislation. ${ }^{10}$ This index measures the procedures and costs involved in dismissing individuals or groups of workers, or in hiring workers on fixed-term or temporary work agency contracts, and takes values on a six-point scale, with higher values corresponding to stricter regulation.

[Figures 7 and 8 here]

Figure 7 shows that recent immigrants in countries with stricter employment protection legislation exhibit an occupational distribution that is more distinct from that of natives, especially for non-EU immigrants. This suggests that in these countries, access to particular occupations is more difficult. However, the gap relative to natives in employment probabilities does not seem to be correlated with the index of employment protection legislation. If anything, it displays a negative correlation with the employment gaps of EU immigrants.

\footnotetext{
${ }^{10}$ Similarly, Angrist and Kugler (2003) and D’Amuri and Peri (2011) argue that the cross-country differences in the impact of immigration on the labour market outcomes of natives across Europe might be due to differences in the flexibility of national labor markets.
} 
Thus, comparisons of figures 5 with 7 warns against too simplistic interpretations of one specific feature of host countries' institutions as a reason for immigrants' labor market disadvantage. Nevertheless, we believe that institutions may play an important part in explaining some of the findings presented in this paper. Identifying those that facilitate the assimilation of immigrants is an important area of future research. 


\section{References}

Angrist, Joshua D. and Adriana Kugler (2003), “Protective or counter-productive? Labor market institutions and the effect of immigration on EU natives”, The Economic Journal, 113 (488), pp. F302-F331.

Blanden, Jo, Gregg, Paul and Lindsey Macmillan (2007), “Accounting for Intergenerational Income Persistence: Noncognitive Skills, Ability and Education”, The Economic Journal, 117, pp. C43-C60.

Carrington, William J. and Kenneth R Troske (1997), “On measuring segregation in samples with small units”, Journal of Business and Economic Statistics, 15, 4, pp. 402-409.

Corak, Miles (2006), “Dynamics of Inequality and Poverty”, Research on Economic Inequality, 13, pp. 143-188.

D’Amuri, Francesco and Giovanni Peri (2011), “Immigration, Jobs and Labor Market Institutions: Evidence from Europe”, NBER Working Paper 17139.

Dustmann, Christian, Casanova, Maria, Preston, Ian, Fertig, Michael and Christoph M. Schmidt (2003), “The Impact of EU Enlargement on Migration Flows.”, Home Office Online Report 25/03, Immigration and Nationality Directorate of the UK, Home Office, London.

Dustmann, Christian, Frattini, Tommaso and Gianandrea Lanzara (2012), "Educational achievement of second generation immigrants: an international comparison”, Economic Policy, 27(69), pp. 143-185.

Dustmann, Christian, Frattini, Tommaso and Anna Rosso (2012), “The Effect of Emigration from Poland on Polish Wages”, CReAM Discussion Paper No. 29/12.

Dustmann, Christian, and Albrecht Glitz (2011), “Migration and Education”, in E. A. Hanushek, S. Machin, and L. Woessmann (Eds.), Handbook of the Economics of Education, Vol. IV, Chapter 4, pp. 327-439.

Fasani, Francesco (2010), “The quest for “La Dolce Vita”? Undocumented migration in Italy”, in Triandafyllidou A. (edited by) “Irregular Migration in Europe: Myths and Realities”, Ashgate.

Ganzeboom, Harry B. G., De Graaf, Paul M., and Donald J. Treiman (1992). “A Standard International Socio-Economic Index of Occupational Status”, Social Science Research, 21 (1), pp. $1-56$. 
Glitz, Albrecht (2012), “The Labor Market Impact of Immigration: A Quasi-Experiment Exploiting Immigrant Location Rules in Germany”, Journal of Labor Economics, Vol. 30 (1), pp. 175-213.

Hellerstein, Judith, Neumark, David and Melissa McInerney (2007), “Changes in workplace segregation in the United States between 1990 and 2000: evidence from matched employeremployee data”, NBER Working Paper 13080.

Hoefer, Michael, Rytina, Nancy and Bryan C. Baker (2010). "Estimates of the Unauthorized Immigrant Population Residing in the United States: January 2009,” Office of Immigration Statistics, Policy Directorate, U.S. Department of Homeland Security.

Jäntti, Markus, Bratsberg, Brent, Røed, Knut, Raaum, Oddbjørn., Naylor, Robin A., Osterbacka, Eva, Bjorklund, Anders and Tor Eriksson (2006), “American exceptionalism in a new light: a comparison of intergenerational earnings mobility in the Nordic countries, the United Kingdom and the United States”, IZA Discussion Paper 1938.

Kovacheva, Vesela, and Dita Vogel (2009). "The size of the irregular foreign resident population in the European Union in 2002, 2005 and 2008: aggregated estimates”, Database on Irregular Migration, Working paper No. 4, HWWI, Hamburg.

McDonald, James R. (1965), “The Repatriation of French Algerians, 1962-63”, International Migration, 3(3), pp. 146-157.

Salt, John and Hugh Clout (eds.) (1976), Migration in Post-War Europe: Geographical Essays, London: Oxford University Press.

Solon, Gary (2002), “Cross-country differences in intergenerational earnings mobility”, Journal of Economic Perspectives, 16(3), 59-66.

Vogel, Dita and Vesela Kovacheva (2009), Calculation table of EU estimate 2008, last change 30 September 2009, Annex 3 to Kovacheva and Vogel (2009). 
Tables

Table 1: Immigrants as a percentage of total population, years 2007-2009

\begin{tabular}{|c|c|c|c|c|c|c|c|c|c|}
\hline & \multirow{2}{*}{$\begin{array}{c}\% \\
\text { Immigrants } \\
\text { in total } \\
\text { population }\end{array}$} & \multicolumn{8}{|c|}{ Composition of immigrant population by area of origin } \\
\hline & & EU15 & NMS12 & $\begin{array}{l}\text { Other } \\
\text { Europe }\end{array}$ & $\begin{array}{c}\text { North } \\
\text { Africa \& } \\
\text { Middle } \\
\text { East }\end{array}$ & $\begin{array}{l}\text { Other } \\
\text { Africa }\end{array}$ & $\begin{array}{l}\text { South } \\
\text { and } \\
\text { East } \\
\text { Asia }\end{array}$ & $\begin{array}{c}\text { North } \\
\text { America } \\
\text { and } \\
\text { Oceania }\end{array}$ & $\begin{array}{c}\text { Latin } \\
\text { America }\end{array}$ \\
\hline Austria & 15.68 & 17.55 & 18.7 & 51.18 & 3.58 & 1.2 & 5.44 & 1.07 & 1.29 \\
\hline Belgium & 11.76 & 41.53 & 6.45 & 13.83 & 18.09 & 10.96 & 5.48 & 1.16 & 2.5 \\
\hline Germany & 14.5 & 25.36 & 8.38 & 46.9 & 7.16 & 2.33 & 6.14 & 2.14 & 1.6 \\
\hline Denmark & 7.98 & 20.05 & 5.39 & 26.27 & 16.12 & 4.76 & 16.75 & 8.04 & 2.63 \\
\hline Spain & 13.09 & 13.83 & 13.76 & 3.89 & 15.13 & 2.86 & 3.28 & 0.65 & 46.6 \\
\hline Finland & 2.71 & 29.86 & 10.51 & 33.75 & 7.16 & 5.08 & 8.89 & 2.73 & 2.02 \\
\hline France & 10.66 & 27.57 & 2.99 & 6.11 & 40.23 & 12.08 & 6.79 & 1.56 & 2.67 \\
\hline Greece & 7.79 & 5.85 & 12.89 & 61.34 & 11.98 & 1.02 & 4.36 & 2.21 & 0.35 \\
\hline Ireland* & 15.59 & 40.16 & 32.66 & 3.21 & 1.54 & 5.71 & 9.59 & 5.6 & 1.53 \\
\hline Italy & 7.41 & 11.37 & 18.11 & 26.72 & 14.03 & 5.48 & 11.27 & 1.81 & 11.2 \\
\hline Netherlands & 10.66 & 17.39 & 3.57 & 16.64 & 17.22 & 5.86 & 17.45 & 2.51 & 19.38 \\
\hline Norway & 8.69 & 30.4 & 5.54 & 14.16 & 11.22 & 7.58 & 20.99 & 4.62 & 5.49 \\
\hline Portugal & 6.48 & 18.51 & 3.06 & 8.31 & 0.23 & 45.04 & 1.73 & 2 & 21.12 \\
\hline Sweden & 15.16 & 26.33 & 8.2 & 21.56 & 20.45 & 4.37 & 10.8 & 1.55 & 6.73 \\
\hline UK & 11.34 & 18.08 & 13.47 & 3.56 & 4.62 & 16.93 & 29.05 & 7.67 & 6.61 \\
\hline Total & 11.27 & 20.61 & 10.63 & 18.91 & 15.39 & 8.34 & 11.25 & 2.83 & 12.03 \\
\hline USA & 12.50 & 7.44 & 3.23 & 2.57 & 2.82 & 3.04 & 24.75 & 2.79 & 53.37 \\
\hline
\end{tabular}

Column 1 reports the share of immigrants in the total population of each country.

Columns 2-9 report the composition of the immigrant population of each country by country of origin.

Immigrants are defined as "foreign born" in all countries in the first column. In columns 2-9, they are defined as "foreign born" in all countries, except for Germany where they are defined as "foreign nationals".

*Data refer to years 2008-09 only.

Source: Europe: EU-LFS, years 2007, 2008 and 2009; USA: 2006-2008 American Community Survey 3-Year Estimates, our elaboration based on US Census Bureau Table B05006 
Table 2: Estimates of undocumented immigrants, 2009

\begin{tabular}{l|cc|cc} 
& \multicolumn{2}{|c|}{ As a \% of total population } & \multicolumn{2}{c}{ As a \% of immigrant population } \\
\hline & Min & Max & Min & Max \\
\hline Austria & $0.22 \%$ & $0.65 \%$ & $2.20 \%$ & $6.50 \%$ \\
Belgium* & $0.82 \%$ & $1.24 \%$ & $9.40 \%$ & $14.20 \%$ \\
Denmark* & $0.02 \%$ & $0.09 \%$ & $0.30 \%$ & $1.70 \%$ \\
France* & $0.28 \%$ & $0.63 \%$ & $4.90 \%$ & $11.00 \%$ \\
Germany & $0.24 \%$ & $0.56 \%$ & $2.70 \%$ & $6.30 \%$ \\
Greece & $1.53 \%$ & $1.86 \%$ & $9.10 \%$ & $19.20 \%$ \\
Ireland* & $0.68 \%$ & $1.41 \%$ & $6.70 \%$ & $13.80 \%$ \\
Italy & $0.47 \%$ & $0.77 \%$ & $9.50 \%$ & $15.70 \%$ \\
Netherlands* & $0.38 \%$ & $0.80 \%$ & $9.10 \%$ & $19.20 \%$ \\
Norway & $0.22 \%$ & $0.68 \%$ & $2.75 \%$ & $8.39 \%$ \\
Portugal* & $0.75 \%$ & $0.94 \%$ & $18.40 \%$ & $23.00 \%$ \\
Spain & $0.62 \%$ & $0.78 \%$ & $6.10 \%$ & $7.70 \%$ \\
Sweden* & $0.09 \%$ & $0.13 \%$ & $1.60 \%$ & $2.40 \%$ \\
UK & $0.68 \%$ & $1.41 \%$ & $11.40 \%$ & $23.60 \%$ \\
EU 15* & $0.46 \%$ & $0.83 \%$ & $6.60 \%$ & $11.90 \%$ \\
\hline Austria & $0.22 \%$ & $0.65 \%$ & $2.20 \%$ & $6.50 \%$ \\
\hline Belgium* & & $0.82 \%$ & \multicolumn{3}{c}{$1.24 \%$} \\
\hline
\end{tabular}

The table reports minimum and maximum estimates of the size of the undocumented immigrant population for each country in 2008, expressed a share of the total country population or as a share of the total immigrant population.

* denotes low-quality estimates

Source: Vogel and Kolacheva (2009) for European countries. Our calculations based on Hoefer et al. (2010) for the US. 
Table 3: Immigration and education

\begin{tabular}{|c|c|c|c|c|c|}
\hline & \multicolumn{2}{|c|}{$\begin{array}{c}\% \text { with lower secondary } \\
\text { education }\end{array}$} & \multicolumn{2}{|c|}{$\%$ with tertiary education } & \multirow{2}{*}{$\begin{array}{c}\text { Standard } \\
\text { deviation of } \\
\text { lower secondary } \\
\text { education } \\
\text { shares across } \\
\text { origin groups }\end{array}$} \\
\hline & Natives & Immigrants & Natives & Immigrants & \\
\hline Austria & 16.33 & 33.93 & 17.51 & 18.07 & 14.00 \\
\hline Belgium & 29.03 & 42.72 & 32.8 & 28.4 & 15.92 \\
\hline Germany & 10.47 & 37.53 & 27.02 & 19.31 & 15.93 \\
\hline Denmark & 23.78 & 27.10 & 33.18 & 33.41 & 10.11 \\
\hline Spain & 50.72 & 40.60 & 30.15 & 24.38 & 19.70 \\
\hline Finland & 19.59 & 24.54 & 36.75 & 31.86 & 10.65 \\
\hline France & 28.38 & 46.07 & 27.58 & 23.98 & 12.68 \\
\hline Greece & 39.25 & 46.08 & 22.9 & 15.69 & 19.09 \\
\hline Ireland & 33.04 & 18.51 & 31.32 & 46.34 & 10.43 \\
\hline Italy & 48.36 & 45.32 & 13.62 & 12.85 & 13.19 \\
\hline Netherlands & 27.18 & 37.91 & 31.14 & 25.91 & 12.71 \\
\hline Norway & 19.90 & 27.02 & 34.01 & 38.51 & 12.34 \\
\hline Portugal & 74.69 & 52.41 & 13.01 & 21.82 & 14.01 \\
\hline Sweden & 15.31 & 25.18 & 30.9 & 31.94 & 9.19 \\
\hline UK & 30.00 & 24.28 & 30.57 & 33.96 & 6.79 \\
\hline Total & 31.74 & 38.05 & 25.83 & 23.51 & 15.4 \\
\hline
\end{tabular}

The table reports the percentage of immigrants and natives in each country with low (column 1) and high (column 2 education). Column 3 reports the standard deviation of the share of individuals with lower secondary education across different immigrant groups within each country. The sample is restricted to working age population older than 25, not in full-time education and not in military service.

We define immigrants as "foreign born" in all countries.

Source: EU-LFS, years 2007, 2008 and 2009 
Table 4: Immigration and education, by area of origin

\begin{tabular}{l|cc} 
& $\begin{array}{c}\text { \% with lower } \\
\text { secondary education }\end{array}$ & $\begin{array}{c}\text { \% with tertiary } \\
\text { education }\end{array}$ \\
\hline Natives & 31.74 & 25.83 \\
\hline EU15 & 35.08 & 29.35 \\
NMS12 & 23.40 & 21.03 \\
Other Europe & 49.01 & 14.74 \\
North Africa and near Middle East & 50.98 & 20.52 \\
Other Africa & 39.01 & 27.84 \\
South and East Asia & 40.04 & 26.26 \\
North America and Oceania & 14.10 & 49.55 \\
Latin America & 37.19 & 22.79 \\
\hline All immigrants & 38.05 & 23.51 \\
\hline
\end{tabular}

The table reports the percentage of natives and immigrants from each area of origin with low (column 1) and high (column 2) education, pooling all destination countries. The sample is restricted to working age population older than 25 , not in full-time education and not in military service.

We define immigrants as "foreign born" in all countries, except for Germany where they are defined as foreign nationals.

Source: EU-LFS, years 2007, 2008 and 2009 
Table 5: Immigrant-native employment rate differentials

\begin{tabular}{|c|c|c|c|c|c|c|}
\hline & $\begin{array}{l}\text { EU } \\
(1)\end{array}$ & $\begin{array}{c}\text { Non-EU } \\
(2)\end{array}$ & $\begin{array}{l}\text { EU } \\
(3)\end{array}$ & $\begin{array}{c}\text { Non-EU } \\
(4)\end{array}$ & $\begin{array}{l}\text { EU } \\
(5)\end{array}$ & $\begin{array}{c}\text { Non-EU } \\
(6)\end{array}$ \\
\hline Austria & $-0.058 * *$ & $-0.128 * *$ & $-0.048 * *$ & $-0.129 * *$ & $-0.059 * *$ & $-0.118 * *$ \\
\hline Belgium & $-0.088 * *$ & $-0.207 * *$ & $-0.062 * *$ & $-0.195^{* *}$ & $-0.029 * *$ & $-0.197 * *$ \\
\hline Germany & $-0.053 * *$ & $-0.219 * *$ & $-0.067 * *$ & $-0.227 * *$ & $-0.032 * *$ & $-0.162 * *$ \\
\hline Denmark & $-0.028 * *$ & $-0.118 * *$ & $-0.029 * *$ & $-0.121 * *$ & $-0.034 * *$ & $-0.146^{* *}$ \\
\hline Spain & -0.006 & -0.003 & -0.008 & $-0.011^{*}$ & $-0.059 * *$ & $-0.044 * *$ \\
\hline Finland & $0.032 *$ & $-0.122 * *$ & 0.030* & $-0.119 * *$ & -0.013 & $-0.150 * *$ \\
\hline France & $-0.065 * *$ & $-0.135^{* *}$ & $-0.074 * *$ & $-0.151 * *$ & -0.010 & $-0.129 * *$ \\
\hline Greece & $0.012 *$ & $0.040 * *$ & $0.045^{* *}$ & $0.026^{* *}$ & 0.003 & 0.003 \\
\hline Ireland & $0.015 * *$ & $-0.028 * *$ & $0.013 * *$ & $-0.027 * *$ & $-0.035 * *$ & $-0.130 * *$ \\
\hline Italy & $0.042 * *$ & $0.048 * *$ & $0.044 * *$ & $0.010 * *$ & $-0.027 * *$ & $-0.032 * *$ \\
\hline Netherlands & $-0.053 * *$ & $-0.149 * *$ & $-0.043^{* *}$ & $-0.147 * *$ & $-0.061^{* *}$ & $-0.156 * *$ \\
\hline Norway & 0.019* & $-0.100 * *$ & 0.014 & $-0.105^{* *}$ & -0.009 & $-0.108 * *$ \\
\hline Portugal & $0.069 * *$ & $0.041^{* *}$ & $0.069 * *$ & $0.042 * *$ & $-0.029 * *$ & $-0.022 * *$ \\
\hline Sweden & $-0.090 * *$ & $-0.158 * *$ & $-0.094 * *$ & $-0.167 * *$ & $-0.079 * *$ & $-0.174 * *$ \\
\hline UK & $0.037 * *$ & $-0.073^{* *}$ & $0.033 * *$ & $-0.076 * *$ & $0.013^{*}$ & $-0.101 * *$ \\
\hline $\begin{array}{lll}\begin{array}{l}\text { Year } \\
\text { effects }\end{array} & \& & \text { quarter } \\
\end{array}$ & Yes & Yes & Yes & Yes & Yes & Yes \\
\hline Gender & No & No & Yes & Yes & Yes & Yes \\
\hline Region effects & No & No & Yes & Yes & Yes & Yes \\
\hline Age & No & No & No & No & Yes & Yes \\
\hline Education & No & No & No & No & Yes & Yes \\
\hline
\end{tabular}

The table reports differences in employment probability between EU (columns 1-3-5) or non-EU (columns 2-4-6) immigrants and natives. The values are the estimated coefficients of separate regressions by country of a dummy for having a job on dummies for EU and non-EU immigrants. Separate regressions are run for each country. The sample are individuals in working-age population not in military service and not in education or training. We define an individual as in employment if she is employed or self-employed.

Year and quarter effects: year-quarter interaction dummies. Gender: dummy for female. Age: dummies for five-year age groups. Education: dummies for lower secondary, secondary and tertiary education.

* difference significant at 10\%, ** difference significant at $1 \%$

Source: EU-LFS, years 2007, 2008 and 2009. 
Table 6: Dissimilarity in occupational distribution

\begin{tabular}{|c|c|c|c|c|c|c|c|c|c|c|}
\hline & $\begin{array}{l}\text { Overa } \\
\text { of diss }\end{array}$ & $\begin{array}{l}\text { index } \\
\text { ilarity }\end{array}$ & $\begin{array}{r}\text { Inde } \\
\mathrm{L}\end{array}$ & $\begin{array}{l}\text { of dis } \\
\mathrm{W}\end{array}$ & $\mathrm{Me}$ & y edu & itiona & & $\begin{array}{r}\text { We } \\
\text { avera } \\
\text { edu }\end{array}$ & $\begin{array}{l}\text { ted } \\
\text { across } \\
\text { tion }\end{array}$ \\
\hline & $\begin{array}{l}\text { EU } \\
(1)\end{array}$ & $\begin{array}{c}\text { Non- } \\
\text { EU } \\
(2)\end{array}$ & $\begin{array}{l}\text { EU } \\
(3)\end{array}$ & $\begin{array}{c}\text { Non- } \\
\text { EU } \\
(4)\end{array}$ & $\begin{array}{l}\text { EU } \\
(5)\end{array}$ & $\begin{array}{c}\text { Non- } \\
\text { EU } \\
(6)\end{array}$ & $\begin{array}{l}\text { EU } \\
(7)\end{array}$ & $\begin{array}{c}\text { Non- } \\
\text { EU } \\
(8)\end{array}$ & $\begin{array}{l}\text { EU } \\
(9)\end{array}$ & $\begin{array}{c}\text { Non- } \\
\text { EU } \\
(10)\end{array}$ \\
\hline Austria & 11.4 & 34.4 & 10.2 & 30.5 & 11.7 & 32.9 & 9.6 & 19.4 & 11.1 & 30.0 \\
\hline Belgium & 9.7 & 18.4 & 9.5 & 12.7 & 7.7 & 12.8 & 10.1 & 16.5 & 9.0 & 14.2 \\
\hline Germany & 12.2 & 26.1 & 12.1 & 16.1 & 11.6 & 19.5 & 0.1 & 13.4 & 8.6 & 17.4 \\
\hline Denmark & 4.1 & 18.3 & 1.8 & 14.5 & 7.6 & 18.1 & 4.1 & 12.8 & 5.0 & 15.5 \\
\hline Spain & 17.1 & 31.4 & 12.6 & 21.4 & 31.9 & 31.0 & 20.0 & 29.7 & 19.8 & 26.6 \\
\hline Finland & 1.2 & 13.4 & 2.1 & 14.8 & 6.7 & 12.0 & 8.4 & 19.5 & 6.6 & 15.3 \\
\hline France & 17.5 & 12.2 & 25.0 & 14.6 & 8.8 & 6.7 & 6.7 & 13.2 & 12.0 & 10.6 \\
\hline Greece & 31.9 & 50.0 & 32.3 & 43.9 & 33.7 & 45.5 & 18.5 & 58.8 & 29.3 & 48.4 \\
\hline Ireland & 12.1 & 19.4 & 9.0 & 12.7 & 19.1 & 20.4 & 14.8 & 12.8 & 15.2 & 15.8 \\
\hline Italy & 27.5 & 36.2 & 19.7 & 19.8 & 41.7 & 42.9 & 19.8 & 44.5 & 29.8 & 34.5 \\
\hline Netherlands & 5.4 & 14.8 & 8.1 & 12.9 & 4.7 & 9.6 & 2.0 & 11.2 & 4.7 & 11.0 \\
\hline Norway & 10.4 & 17.2 & 11.3 & 9.4 & 9.0 & 19.2 & 9.7 & 19.6 & 9.7 & 17.3 \\
\hline Portugal & 8.3 & 12.2 & 5.0 & 15.3 & 15.2 & 26.6 & 6.9 & 15.6 & 7.0 & 17.2 \\
\hline Sweden & 4.7 & 20.8 & 6.0 & 19.6 & 1.8 & 21.0 & 8.3 & 25.8 & 4.5 & 22.3 \\
\hline UK & 12.5 & 9.9 & 18.7 & 15.3 & 18.1 & 12.2 & 2.8 & 4.4 & 13.1 & 10.3 \\
\hline
\end{tabular}

The table reports the Duncan dissimilarity index for the distribution of EU (odd columns) and non-EU (even columns) immigrants and natives across 1-digit ISCO occupations. Columns 1-2 reports the overall index. Columns 3-8 report the index by education group. Columns 9 and 10 report the average of the index by education group weighted by the share of total population in each education group.

Source: EULFS, 2007-2009 
Table 7: Immigrant-native occupational differences

\begin{tabular}{|c|c|c|c|c|c|c|}
\hline & $\begin{array}{c}\text { EU } \\
(1) \\
\end{array}$ & $\begin{array}{c}\text { Non-EU } \\
(2)\end{array}$ & $\begin{array}{r}\text { EU } \\
(3) \\
\end{array}$ & $\begin{array}{c}\text { Non-EU } \\
(4)\end{array}$ & \begin{tabular}{|c|c} 
EU \\
$(5)$ \\
\end{tabular} & $\begin{array}{c}\text { Non-EU } \\
(6) \\
\end{array}$ \\
\hline Austria & $0.075 * *$ & $-0.584 * *$ & $-0.103 * *$ & $-0.429 * *$ & $-0.053 * *$ & $-0.047 * *$ \\
\hline Belgium & $0.039 * *$ & $-0.350 * *$ & -0.010 & $-0.294 * *$ & -0.006 & $-0.082 * *$ \\
\hline Germany & $-0.181^{* *}$ & $-0.509 * *$ & $-0.103^{* *}$ & $-0.295 * *$ & $-0.049 * *$ & $-0.066^{* *}$ \\
\hline Denmark & $0.064^{*}$ & $-0.310 * *$ & $-0.076^{* *}$ & $-0.248 * *$ & $-0.026^{* *}$ & $-0.044^{* *}$ \\
\hline Spain & $-0.405^{* *}$ & $-0.620 * *$ & $-0.445^{* *}$ & $-0.492 * *$ & $-0.082 * *$ & $-0.081^{* *}$ \\
\hline Finland & $0.073 *$ & $-0.199 * *$ & $0.113^{* *}$ & $-0.141^{* *}$ & 0.008 & $-0.038 * *$ \\
\hline France & $-0.232 * *$ & $-0.173 * *$ & $-0.182^{* *}$ & $-0.232 * *$ & $-0.029 * *$ & $-0.036 * *$ \\
\hline Greece & $-0.525^{* *}$ & $-0.845^{* *}$ & $-0.477 * *$ & $-0.591^{* *}$ & $-0.112 * *$ & $-0.121^{* *}$ \\
\hline Ireland & $-0.263^{* *}$ & -0.008 & $-0.249 * *$ & $-0.221^{* *}$ & 0.001 & $-0.108 * *$ \\
\hline Italy & $-0.603^{* *}$ & $-0.779 * *$ & $-0.595 * *$ & $-0.634^{* *}$ & $-0.114^{* *}$ & $-0.125^{* *}$ \\
\hline Netherlands & 0.028 & $-0.344^{* *}$ & $-0.100 * *$ & $-0.252 * *$ & 0.007 & $-0.026^{* *}$ \\
\hline Norway & $0.158 * *$ & $-0.317 * *$ & $-0.049 *$ & $-0.336 * *$ & -0.015 & $-0.056 * *$ \\
\hline Portugal & $0.295 * *$ & -0.006 & $-0.111^{* *}$ & $-0.317 * *$ & $-0.024 *$ & $-0.071^{* *}$ \\
\hline Sweden & 0.006 & $-0.333^{* *}$ & $-0.118 * *$ & $-0.381 * *$ & $0.010 * *$ & $-0.036 * *$ \\
\hline UK & $-0.208^{* *}$ & $0.069 * *$ & $-0.237 * *$ & $-0.115^{* *}$ & $-0.039 * *$ & $-0.030 * *$ \\
\hline $\begin{array}{l}\text { Year \& quarter } \\
\text { effects }\end{array}$ & Yes & Yes & Yes & Yes & Yes & Yes \\
\hline Gender & No & No & Yes & Yes & Yes & Yes \\
\hline Region effects & No & No & Yes & Yes & Yes & Yes \\
\hline Age & No & No & Yes & Yes & Yes & Yes \\
\hline Education & No & No & Yes & Yes & Yes & Yes \\
\hline 1-digit Occupation & No & No & No & No & Yes & Yes \\
\hline
\end{tabular}

This table reports the differences (as fractions of a country-specific standard deviation) in Socio-Economic Index (SEI) of EU (columns 1-3-5) and non-EU (columns 2-4-6) immigrant workers relative to native workers. The values are the estimated coefficients of separate regressions by country of the ISEI index (normalized by its standard deviation) on dummies for EU and non-EU immigrants and year-quarter interaction dummies (columns 1-2), and other control variables (columns 3-6). Year and quarter effects: year-quarter interaction dummies. Gender: dummy for female. Region: regional dummies. Age: dummies for five-year age groups. Education: dummies for lower secondary, secondary and tertiary education. 1digit occupation: dummies for 1-digit ISCO codes.

* difference significant at 10\%, ** difference significant at $1 \%$ Source: EU-LFS, 2007-2009. 
Table 8: Position in national earnings distribution

\begin{tabular}{l|cccccccccc} 
& \multicolumn{8}{|c}{ Decile of national earnings distribution } \\
& 1 & 2 & 3 & 4 & 5 & 6 & 7 & 8 & 9 & 10 \\
\hline Natives & 9.6 & 9.7 & 9.3 & 10.0 & 10.1 & 10.4 & 10.0 & 10.2 & 10.4 & 10.5 \\
\hline EU15 & 11.8 & 10.7 & 8.2 & 9.0 & 8.9 & 9.2 & 10.3 & 10.0 & 10.8 & 11.3 \\
NMS12 & 18.9 & 17.3 & 13.0 & 13.0 & 11.1 & 6.9 & 7.5 & 5.5 & 4.2 & 2.8 \\
Other Europe & 16.1 & 15.2 & 10.9 & 10.7 & 9.7 & 9.2 & 9.4 & 8.3 & 6.7 & 3.8 \\
N.Africa \& Middle & & & & & & & & & & \\
East & 12.8 & 12.7 & 12.7 & 11.4 & 11.9 & 8.2 & 7.5 & 7.2 & 7.1 & 8.6 \\
Other Africa & 13.7 & 15.2 & 15.0 & 11.4 & 13.2 & 8.0 & 6.6 & 6.3 & 5.5 & 5.1 \\
South and East Asia & 17.0 & 19.7 & 12.0 & 13.7 & 9.0 & 7.6 & 6.5 & 5.3 & 4.8 & 4.5 \\
N.America \& Oceania & 7.9 & 6.9 & 11.6 & 10.3 & 10.6 & 9.2 & 6.0 & 9.9 & 8.6 & 19.0 \\
Latin America & 20.8 & 19.8 & 11.8 & 9.4 & 10.4 & 6.2 & 5.4 & 4.7 & 6.1 & 5.4 \\
\hline
\end{tabular}

The table reports the percentage of natives and immigrants in each decile of the national earnings distribution in Belgium, Germany, Finland, France and Italy pooled. We define immigrants as "foreign born" in all countries except for Germany, where they are defined as foreign nationals.

Source: EULFS, 2009

Table 9: Immigrant-native differential probability of being in bottom earnings decile

\begin{tabular}{l|cc|cc|cc} 
& EU & Non-EU & EU & Non-EU & EU & Non-EU \\
& $(1)$ & $(2)$ & $(3)$ & $(4)$ & $(5)$ & $(6)$ \\
\hline Belgium & $0.035^{* *}$ & $0.054^{* *}$ & $0.032^{* *}$ & $0.048^{* *}$ & $0.029^{* *}$ & $0.022^{* *}$ \\
Germany & $0.032^{*}$ & $0.065^{* *}$ & $0.023^{*}$ & $0.037^{* *}$ & 0.016 & 0.016 \\
Finland & -0.030 & $0.114^{* *}$ & -0.016 & $0.126^{* *}$ & -0.020 & $0.110^{* *}$ \\
France & $0.028^{* *}$ & $0.037^{* *}$ & $0.029^{* *}$ & $0.053^{* *}$ & $0.016^{*}$ & $0.032^{* *}$ \\
Italy & $0.093^{* *}$ & $0.068^{* *}$ & $0.073^{* *}$ & $0.067^{* *}$ & $0.024^{* *}$ & $0.016^{* *}$ \\
\hline Quarter effects & Yes & Yes & Yes & Yes & Yes & Yes \\
Gender & No & No & Yes & Yes & Yes & Yes \\
Region effects & No & No & Yes & Yes & Yes & Yes \\
Age & No & No & Yes & Yes & Yes & Yes \\
Education & No & No & Yes & Yes & Yes & Yes \\
1-digit Occupation & No & No & No & No & Yes & Yes \\
\hline
\end{tabular}

The table reports differences in probability of being in the bottom decile of the national earnings distribution between EU (columns 1-3-5) or non-EU (columns 2-4-6) immigrants and natives. The values are the estimated coefficients of separate regressions by country of a dummy for being in the bottom decile of the earnings distribution on dummies for EU and non-EU immigrants. Separate regressions are run for each country. Quarter effects: quarter dummies. Gender: dummy for female. Age: dummies for five-year age groups. Education: dummies for lower secondary, secondary and tertiary education.

* difference significant at 10\%, ** difference significant at $1 \%$

Source: EU-LFS, 2009. 
Table 10: Children in Immigrant households

\begin{tabular}{|c|c|c|c|c|c|c|c|}
\hline & \multicolumn{5}{|c|}{$\begin{array}{c}\text { Percentage of children }(<15) \text { who live in an } \\
\text { immigrant household }\end{array}$} & \multicolumn{2}{|c|}{$\begin{array}{l}\text { Percentage of immigrants } \\
\text { in adult population }\end{array}$} \\
\hline & $E U$ & Non-EU & $\begin{array}{c}\text { EU/Non- } \\
\text { EU }\end{array}$ & $\begin{array}{l}\text { Mixed } \\
\text { EU/ } \\
\text { Native }\end{array}$ & $\begin{array}{c}\text { Non-EU/ } \\
\text { Native }\end{array}$ & $E U$ & Non-EU \\
\hline Austria & 3.16 & 17.47 & 0.66 & 4.47 & 4.32 & 5.21 & 8.36 \\
\hline Belgium & 4.09 & 10.69 & 0.69 & 3.78 & 5.11 & 5.08 & 5.49 \\
\hline Germany & 1.68 & 7.97 & 0.38 & 2.89 & 6.05 & 2.11 & 3.8 \\
\hline Spain & 1.8 & 8.04 & 0.21 & 2.92 & 3.43 & 3.39 & 8.51 \\
\hline France & 1.68 & 10.08 & 0.28 & 2.94 & 6.52 & 2.89 & 6.99 \\
\hline Greece & 0.93 & 9.68 & 0.08 & 2.16 & 2.4 & 1.18 & 5.4 \\
\hline Ireland & 7.73 & 4.94 & 0.61 & 9.86 & 2.41 & 8.96 & 3.3 \\
\hline Italy & 1.66 & 7.81 & 0.17 & 2.94 & 3.91 & 1.72 & 4.6 \\
\hline Netherlands & 0.84 & 12.9 & 0.35 & 3.11 & 6.18 & 1.5 & 8.14 \\
\hline Portugal & 0.68 & 5.89 & 0.32 & 3.24 & 6.59 & 0.54 & 4.02 \\
\hline UK & 2.12 & 11.03 & 0.48 & 2.37 & 5.06 & 3.03 & 7.44 \\
\hline Total & 1.86 & 9.43 & 0.34 & 2.95 & 5.16 & 2.58 & 5.96 \\
\hline
\end{tabular}

The left panel of the table reports the share of children under the age of 15 who live in an immigrant or a mixed household. The right panel reports the share of immigrants in the total population above the age of 15.

EU (Non-EU) households are defined as households where the reference person and her or his spouse - if there is a spouse - is an EU(Non-EU) immigrant. Mixed households are households where the reference person and her or his partner have a different immigrant status. We define immigrants as "foreign born" in all countries except for Germany, where they are defined as foreign nationals.

Source: EULFS, 2007-2009. 
Table 11: Households with both spouses in bottom decile of earnings distribution

\begin{tabular}{|c|c|c|c|c|c|c|c|}
\hline & \multirow{2}{*}{$\begin{array}{l}\text { Percentage of } \\
\text { households } \\
\text { with both } \\
\text { spouses in } \\
\text { bottom decile } \\
\text { of earnings } \\
\text { distribution }\end{array}$} & \multirow{2}{*}{$\begin{array}{c}\text { Percentage of } \\
\text { children }(<15) \\
\text { in households } \\
\text { with both } \\
\text { parents in } \\
\text { bottom decile } \\
\text { of earnings } \\
\text { distribution }\end{array}$} & \multicolumn{5}{|c|}{$\begin{array}{c}\text { Percentage of children }(<15) \text { in immigrant } \\
\text { household out of all children in households } \\
\text { with both parents in bottom decile of the } \\
\text { earnings distribution }\end{array}$} \\
\hline & & & $E U$ & $\begin{array}{c}\text { Non- } \\
\text { EU }\end{array}$ & $\begin{array}{c}\text { EU/Non- } \\
\text { EU }\end{array}$ & $\begin{array}{c}\text { EU/ } \\
\text { Native }\end{array}$ & $\begin{array}{c}\text { Non-EU/ } \\
\text { Native }\end{array}$ \\
\hline Belgium & 4.88 & 4.60 & 6.50 & 23.01 & 0.22 & 2.86 & 3.39 \\
\hline Germany & 1.15 & 0.80 & 0 & 19.19 & 0 & 0 & 5.25 \\
\hline France & 4.22 & 3.35 & 2.54 & 19.11 & 0.08 & 0.69 & 5.70 \\
\hline Italy & 4.05 & 3.30 & 5.55 & 20.06 & 0.11 & 2.01 & 3.03 \\
\hline Total & 2.98 & 2.53 & 3.62 & 19.84 & 0.10 & 1.26 & 4.57 \\
\hline
\end{tabular}

The first column of the table reports the percentage of households where the reference person and her/his spouse (if they have a spouse with positive earnings) are both in the bottom decile of the national earnings distribution.

Column 2 reports the percentage of children under the age of 15 living in a household with both parents (or the lone parent) in the bottom decile of the national earnings distribution.

Columns 3-7 report the percentage of children under the age of 15 living in an immigrant or a mixed household out of total households with both parents (or the lone parent) in the bottom decile of the national earnings distribution.

EU (Non-EU) households are defined as households where the reference person and her or his spouse - if there is a spouse - is an EU (Non-EU) immigrant. Mixed households are households where the reference person and her or his partner have a different immigrant status. We define immigrants as "foreign born" in all countries except for Germany, where they are defined as foreign nationals.

Source: EULFS, 2009. 
Figures

Figure 1: Immigrant-native employment differentials

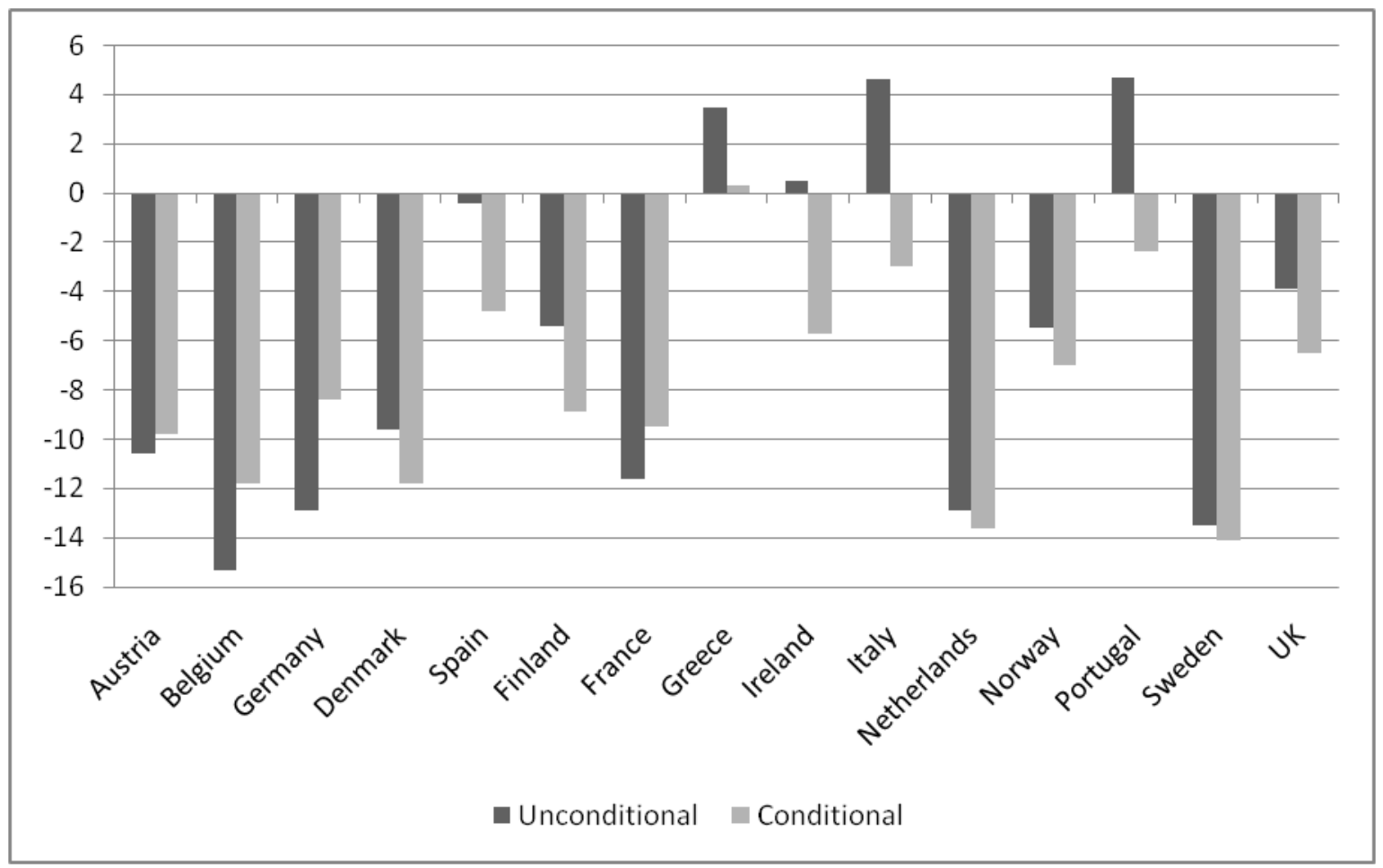

The figure reports percentage points difference in employment probability between immigrants and natives in working age and not in education. Dark columns report unconditional differences (net of year and seasonality effects), while light columns report differences conditional on gender, age, education, and regional distribution.

The differences in employment probabilities are obtained from regressions of a dummy for employment on a dummy for immigrants. Separate regressions by country.

Source: EULFS 2007-2009 
Figure 2: Occupational dissimilarity and years since migration
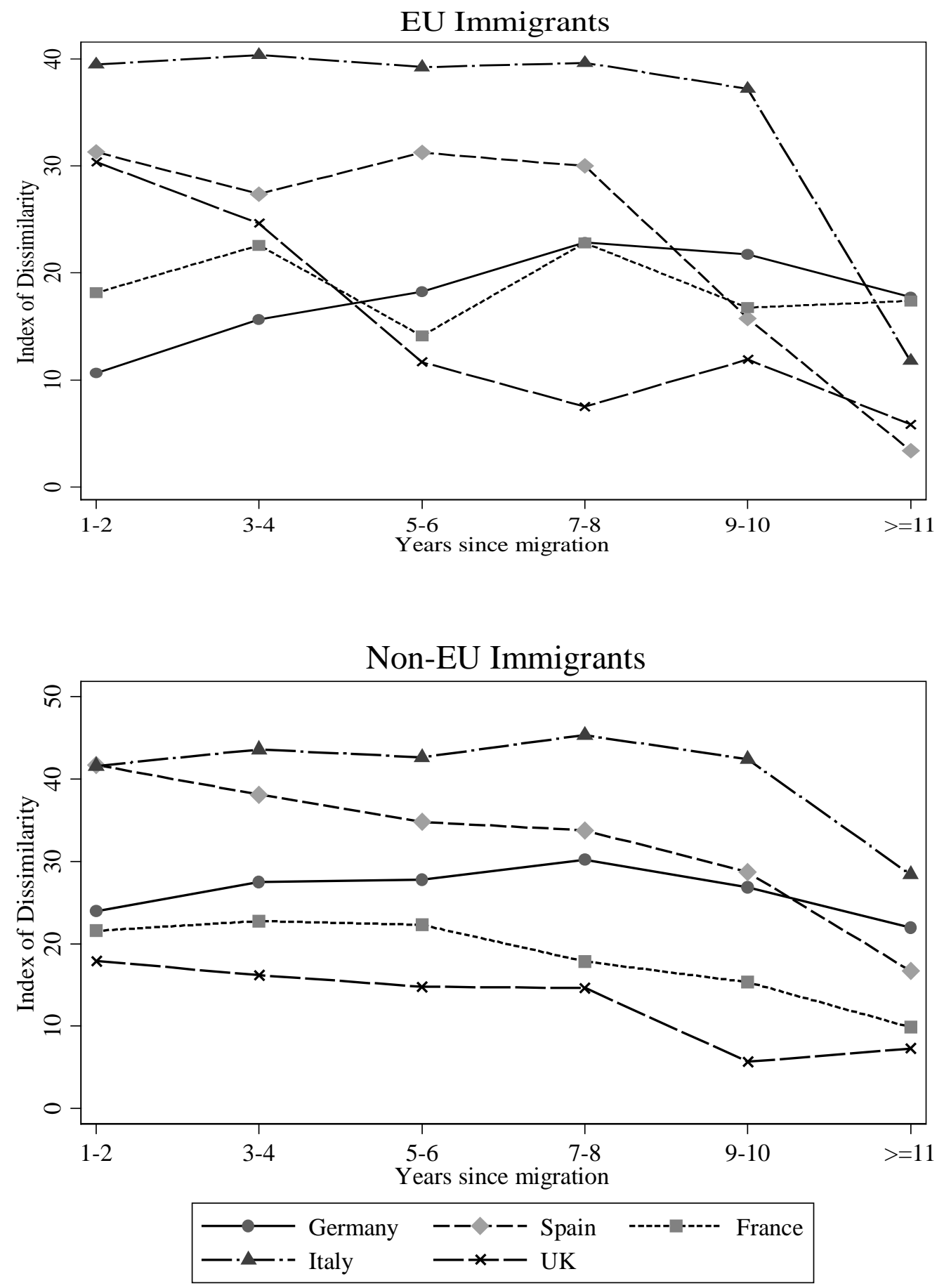

The figure plots the value of the effective Duncan dissimilarity index for occupation of EU immigrants (top graph) and non-EU immigrants (bottom graph) relative to natives versus years since migration in five destination countries.

Source: EULFS 2007-2009 
Figure 3 - Occupational distribution of immigrants and natives

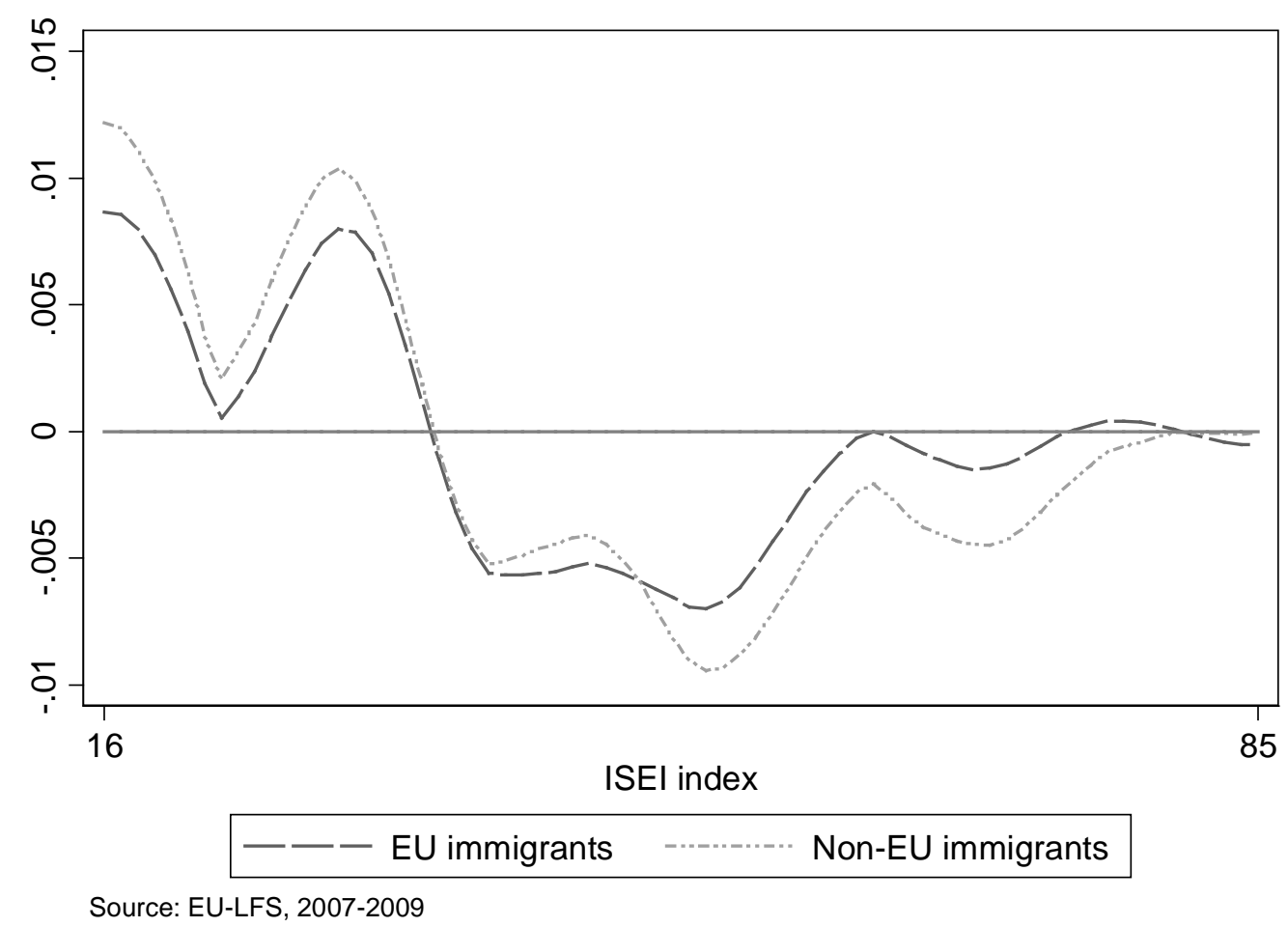

The figure reports differences between kernel density estimates of the distribution of immigrants and the distribution of natives across the ISEI scale.

Source: EULFS 2007-2009 
Figure 4: Immigrant and native earnings distribution

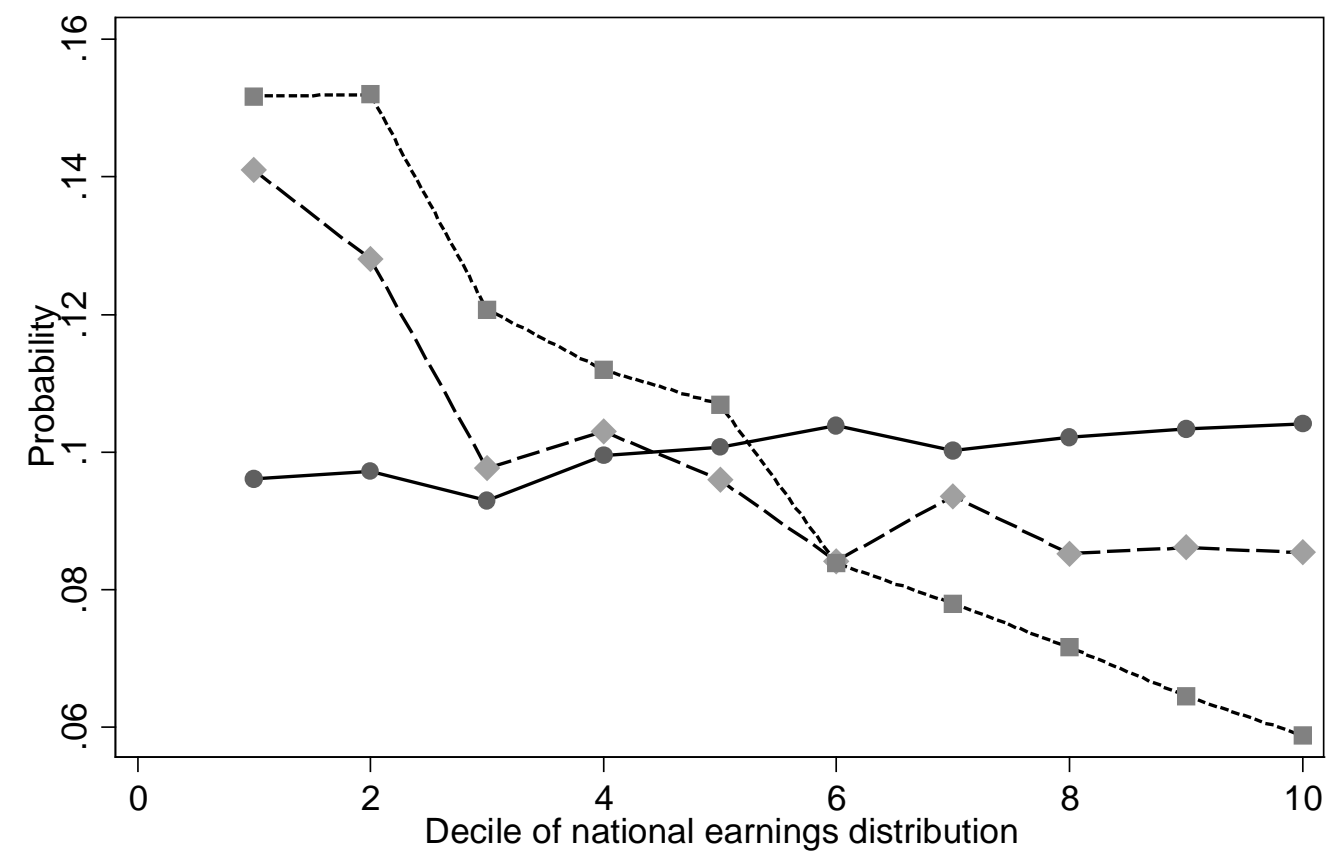

$\longrightarrow$ Natives - - --- EU immigrants ---------- Non-EU immigrants

The figure reports the share of natives (circles), EU immigrants (rhomb) and non-EU immigrants (squares) in each decile of the national earnings distribution in Belgium, Germany, Finland, France and Italy pooled.

Source: EULFS 2009. 
Figure 5 - Historical Immigration and occupational dissimilarity
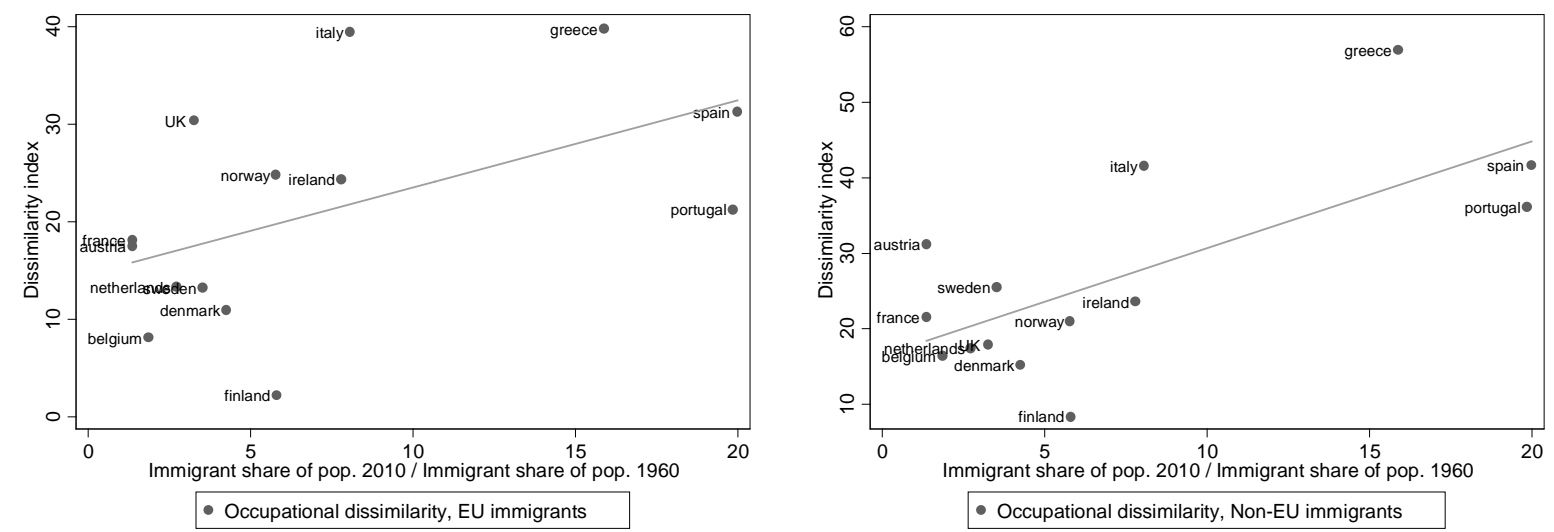

The figure plots for each country the index of occupational dissimilarity between recent EU immigrants and natives (left) and recent non-EU immigrants and natives (right) from Table 6 versus the ratio of the share of immigrants in the total population in 2010 to the share of immigrants in the total population in 1960. We define recent immigrants as immigrants who have been in the country for no more than two years.

Immigration Data Source: World Bank World Development Indicators.

Figure 6 - Historical immigration and gaps in employment probability
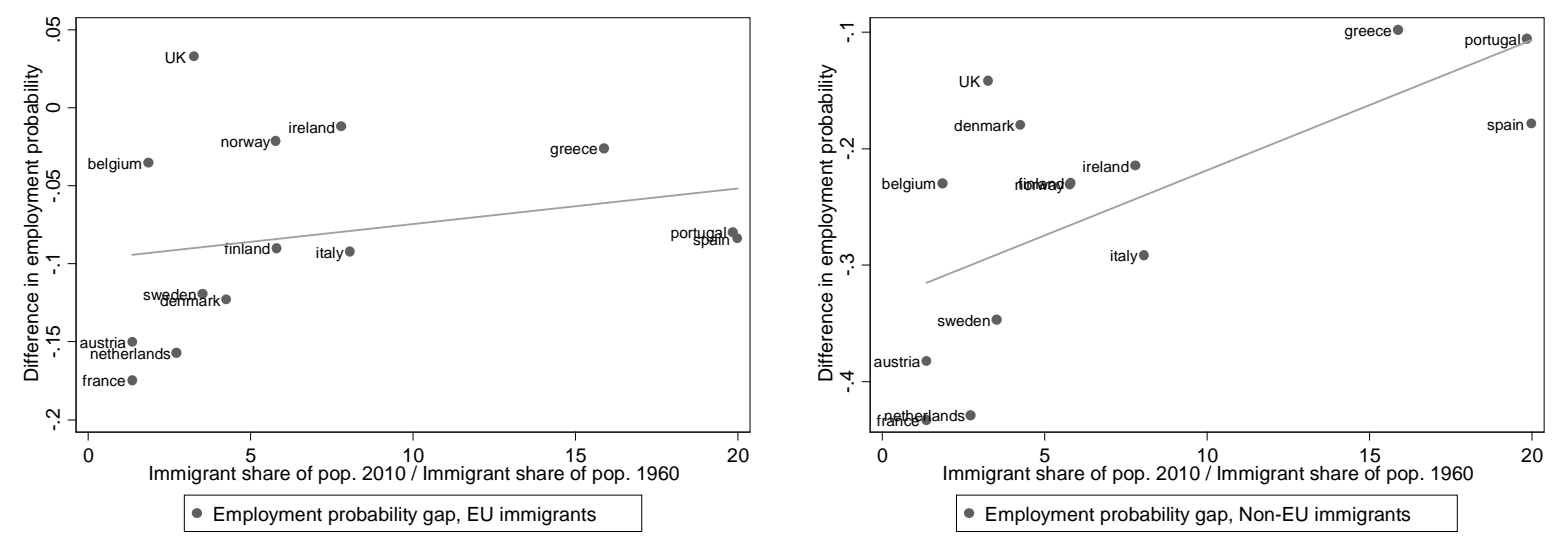

The figure plots for each country the conditional employment probability differentials between recent EU immigrants and natives (left) and recent non-EU immigrants and natives (right) versus the ratio of the share of immigrants in the total population in 1960 to the share of immigrants in the total population in 2010 versus. We define recent immigrants as immigrants who have been in the country for no more than two years. Gaps in employment probabilities are conditional on age, education, region, and gender.

Immigration Data Source: World Bank World Development Indicators. 
Figure 7 - Employment protection legislation and occupational dissimilarity
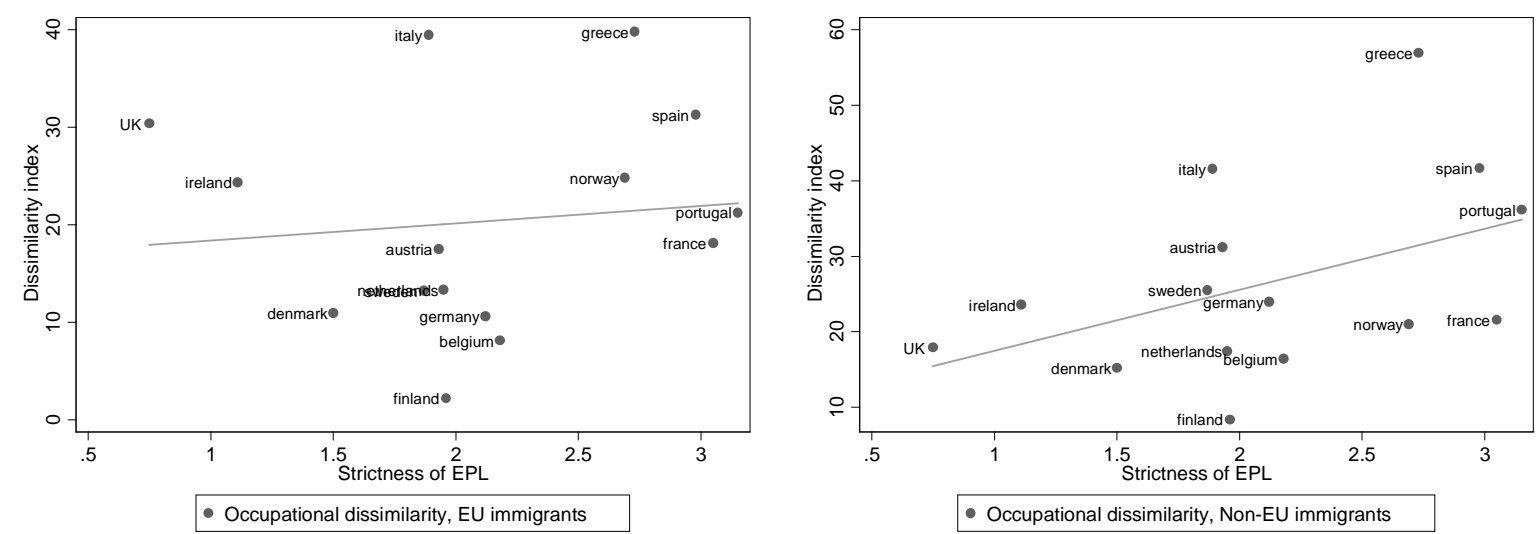

The figure plots for each country the index of occupational dissimilarity between recent EU immigrants and natives (left) and recent non-EU immigrants and natives (right) from Table 6 versus the OECD index of strictness of employment protection legislation in year 2008. We define recent immigrants as immigrants who have been in the country for no more than two years.

Figure 8 - Employment protection legislation and gaps in employment probability
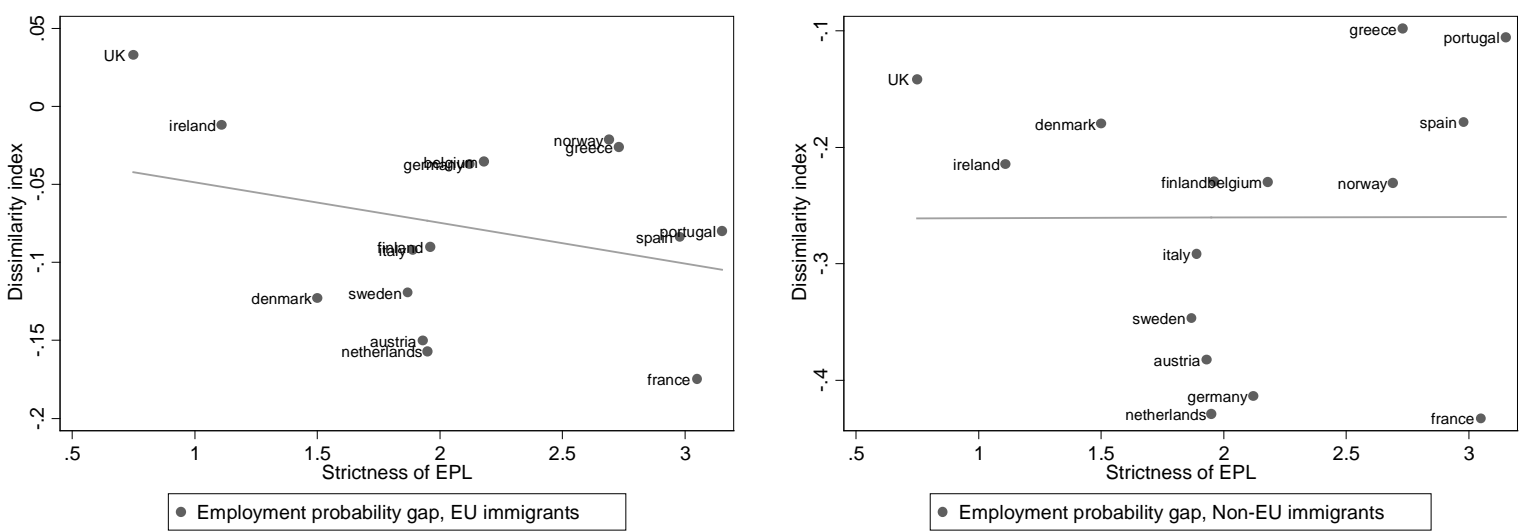

The figure plots for each country the conditional employment probability differentials between recent EU immigrants and natives (left) and recent non-EU immigrants and natives (right) versus the OECD index of strictness of employment protection legislation in year 2008. We define recent immigrants as immigrants who have been in the country for no more than two years. Gaps in employment probabilities are conditional on age, education, region, and gender. 